\title{
MONEY AND POLITICS: \\ THE EFFECTS OF CAMPAIGN SPENDING LIMITS ON \\ POLITICAL COMPETITION AND INCUMBENCY ADVANTAGE
}

\author{
Eric Avis \\ Claudio Ferraz \\ Frederico Finan \\ Carlos Varjão \\ Working Paper 23508 \\ http://www.nber.org/papers/w23508
NATIONAL BUREAU OF ECONOMIC RESEARCH
1050 Massachusetts Avenue
Cambridge, MA 02138
June 2017

The views expressed herein are those of the authors and do not necessarily reflect the views of the National Bureau of Economic Research.

NBER working papers are circulated for discussion and comment purposes. They have not been peer-reviewed or been subject to the review by the NBER Board of Directors that accompanies official NBER publications.

(C) 2017 by Eric Avis, Claudio Ferraz, Frederico Finan, and Carlos Varjão. All rights reserved. Short sections of text, not to exceed two paragraphs, may be quoted without explicit permission provided that full credit, including $\odot$ notice, is given to the source. 
Money and Politics: The Effects of Campaign Spending Limits on Political Competition and Incumbency Advantage

Eric Avis, Claudio Ferraz, Frederico Finan, and Carlos Varjão

NBER Working Paper No. 23508

June 2017

JEL No. H0,O0

\section{ABSTRACT}

This paper examines the effects of campaign spending limits on political competition and incumbency advantage. We study a reform in Brazil that imposed limits on campaign spending for mayoral elections. These limits were implemented with a discontinuous kink which we exploit for causal identification. We find that stricter limits increase political competition by creating a larger pool of candidates that is on average less wealthy. Moreover, we find that stricter spending limits reduce the incumbency advantage, causing mayors to be less likely to be reelected. These findings are consistent with a contest model with spending caps and endogenous candidate entry.

Eric Avis

University of California at Berkeley

eavis@berkeley.edu

Claudio Ferraz

Department of Economics

PUC-Rio

Rio de Janeiro, RJ, 22453-900

Brazil

cferraz@econ.puc-rio.br
Frederico Finan

Department of Economics

University of California

508-1 Evans Hall \#3880

Berkeley, CA 94720-3880

and NBER

ffinan@econ.berkeley.edu

Carlos Varjão

Stanford University

Graduate School of Business

655 Knight Way

Stanford, CA 94305

cvarjao@stanford.edu 


\section{Introduction}

Among the many factors critical for a properly functioning democracy, few have been as widely debated as campaign financing. For some, money in politics serves as an expression of free speech and an effective instrument for informing voters and building an inclusive democracy. For others, the unrestrained use of money in politics can erode the functioning of democracy as it can lead to excessive campaigning, unequal access to power, and politicians who are beholden to special interest groups. ${ }^{1}$

In practice, almost every country with political pluralism has adopted some type of political finance regulation ranging from information and disclosure requirements to limits on campaign contributions and/or expenditures (Scarrow, 2007). Countries such as Canada and the UK have been limiting campaign spending by parties and individuals for many decades. ${ }^{2}$ More recently Belgium, Chile, France, Israel, New Zealand, South Korea and many others have also adopted campaign spending caps aiming at limiting the role of money in elections. ${ }^{3}$

Despite the widespread adoption of spending limits, their impact on the political process has been difficult to quantify. Theoretically, campaign spending limits affect the behavior of both incumbent politicians and challengers. Their effects depend on whether incumbents have a higher voter disposition, whether their fund-raising efficiency is different, and whether they have different campaign spending effectiveness (Che and Gale, 1998; Pastine and Pastine, 2012). Moreover while most existing models consider the case of two candidates, in many political environments an incumbent might compete against multiple challengers and the number of challengers that decide to run for an election depend on their expectations of campaign financing and spending.

Testing the effects of spending limits empirically is challenging because campaign finance reform is usually applied uniformly across elections and jurisdictions, making it difficult to identify an appropriate comparison group. Moreover, spending caps might potentially affect not only the identity of who is elected, but also who chooses to run. Few countries provide information on their non-elected candidates, their characteristics, and their campaign spending patterns, which renders

\footnotetext{
${ }^{1}$ For example, see Coate (2004), Prat (2002), Prat (2006), and Scarrow (2007).

${ }^{2}$ Currently, political parties in Canada can spend only 73.5 cents for every voter in districts in which they are competing. In the United Kingdom, legislation regulating expenditures has been in place since the Corrupt and Illegal Practices Prevention Act 1883. In the 2005 general election, campaign expenditure at the national level were limited to approximately US $\$ 42,000$ per constituency contested.

${ }^{3}$ Two thirds of the OECD countries have introduced campaign spending limits for parties or candidates (Speck, 2013). One of the few exceptions among rich countries is the U.S. where the Supreme Court ruled mandatory spending limits as an unconstitutional curtailment of free speech.
} 
an analysis on the effects of spending caps woefully incomplete.

In this paper, we provide (to our knowledge) the first causal estimates of the effects of campaign spending limits on political entry and selection. We do so in the context of a recent campaign finance reform in Brazil. Amid a massive corruption scandal that included the diversion of public funds to political campaigns, the Brazilian Supreme Court in 2015 decided to ban corporate donations and congress passed a law that imposed campaign spending limits in future elections. The spending caps, which vary by municipality, created a discontinuous kink in the amount candidates could spend in local elections. We exploit this discontinuity together with a rich dataset on all candidates elected and non-elected to explore how spending limits affect the entry decisions of candidates, their characteristics, and electoral results for mayors.

Our analysis, which focuses on municipalities near the point of discontinuity, shows that places subject to lower spending limits are more politically competitive (attract more candidates). Our estimates suggest that a 25 percent decrease in spending caps leads to a 9 percent increase in the number of individuals who run for office, and an average candidate who is 40 percent less wealthy. Our results show that spending limits also affect political selection. We find that re-election rates are 11 percentage points lower in places with more stringent spending caps, suggesting that spending limits reduce incumbency advantage. We also find evidence that more stringent spending caps lead to the election of less wealthy candidates, and of candidates who spend less of their own funds in their campaigns.

Our findings contribute directly to a large literature that examines the effects of regulating campaign spending (Austen-Smith, 1987; Coate, 2004; Ashworth, 2006; Prat, 2002). While there is a rich theoretical literature studying the effects of limits on campaign donations and spending (Che and Gale, 1998; Fang, 2002; Pastine and Pastine, 2012; Cotton, 2012), empirical studies are rare. The key challenge to causal identification is the potential endogeneity of spending caps. Indeed, while many polities around the world have implemented spending limits, their presence and magnitude are likely to be correlated with other unobserved factors which also affect potential outcomes. Stratmann and Aparicio-Castillo (2006) study the effects of the introduction of contribution limits at the state-level in the U.S. They find evidence that limits on giving narrow winning candidates' margin of victory, and increase the number of candidates. To our knowledge, the only other empirical investigation of the effects of campaign spending limits is Milligan and Rekkas (2008), who study spending caps in Canadian federal elections. Exploiting the fact that limits are set by a formula which is a function of the number and the density of electors within each federal district, the authors find that higher limits are correlated with higher incumbent spending, fewer candidates, 
and lower voter turnout. Different from these studies, we study the effects of spending limits on a series of novel outcomes including detailed candidate characteristics and sources of campaign contributions. Furthermore, our research design has the advantage that it requires weaker assumptions to identify the causal effect of spending limits.

Our study also relates to a large literature that examines the effects of campaign spending on electoral outcomes (e.g Levitt (1994), Gerber (1998), Erikson and Palfrey (2000), Da Silveira and De Mello (2011)). Although this relationship is an important input into the design of any campaign finance reform, it is only one piece of the puzzle. As our findings highlight, campaign finance also affects not only who enters but how many. Accounting for these entry decisions thus becomes critical when using any estimate of the effects of campaign spending on electoral outcomes to guide policy.

Finally, our work also speaks to research on the identity of politicians and whether limits to campaign spending might level out the playing field between richer and poorer candidates. There is a growing literature following the citizen-candidate models of Osborne and Slivinski (1996) and Besley and Coate (1997) suggesting that identity matters for policy implementation (Chattopadhyay and Duflo, 2004; Pande, 2003; Besley et al., 2011). In countries where inequality is high, the access to political power might be easier for richer candidates and this might have direct consequences on politicians elected and policies implemented. Our work suggests that imposing spending caps reduces the average wealth of candidates that run and are elected for a mayor position.

The rest of the paper is organized as follows. Section 2 describes Brazil's campaign financing laws and presents the data used in the empirical analysis. Section 3 presents the theoretical framework. Section 4 discusses our research design and in Section 5 we present our findings. Section 6 concludes.

\section{Background and Data}

In this section, we describe Brazil's new campaign financing law, which was established in 2015 in response to a political corruption scandal that continues to engulf the country. The law limits how much candidates from particular municipalities can spend. These spending limits form the basis of our identification strategy. We then discuss our data, and present some basic descriptive statistics. 


\subsection{Municipal Elections and Campaign Financing}

Local elections in Brazil are held every four years, with the most recent election taking place in October of 2016. The elections are held to elect a municipal mayor and a local council. For municipalities with less than 200,000 registered voters, which represents 98.3 percent of all municipalities, mayors are elected based on simple plurality. For municipalities with 200,000 or more registered voters, candidates for mayor must be elected with at least 50 percent of the votes or a second round runoff is held. Once elected, mayors then face a two-term limit. In contrast, local legislators are elected based on an open-list political representation system, and can be reelected indefinitely. Mayors are important political figures in Brazil. Each year, municipalities receive millions of dollars from federal and state governments to provide basic public services such as primary education, health care, and sanitation. The mayor is the agenda setter in how the resources are spent and allocated. ${ }^{4}$

Campaign funding and spending disclosures are tightly regulated in Brazil. All money received by candidates is deposited in a single bank account and all transactions need to be reported to the Electoral Court and are publicly available. If a candidate does not report accurately his campaign expenditures, he may lose office, become ineligible for 8 years, and/or face criminal charges. Before the 2015 electoral reform, individuals were limited to contributing $10 \%$ of their annual income while corporations were limited to contribute $2 \%$ of gross annual revenues. Despite these individual limits, there were no limits on total contributions and campaign spending.

On March 14, 2014, Brazil's Federal Police launched an investigation into a local money laundering scheme involving gas stations. This investigation, entitled "Lava Jato", has since become one of the largest corruption scandals in the world as investigators uncovered a large corruption scheme involving Petrobras and the largest construction companies in Brazil. Since then, investigators have already uncovered over $\mathrm{R} \$ 6$ billion in paid bribes, charged over 175 people with criminal offenses, and secured 93 convictions. Among those convicted, included key members of Brazil's Workers' Party (PT), the PP and the PMDB who were found guilty of diverting billions of dollars through procurement contracts to fund their political campaigns.

As one of the fallouts of the scandal, Brazil's Supreme Court banned all corporate donations to candidates and parties. Candidates can only receive contributions from their political parties (mostly from a state party fund), citizens, or self-financing. This decision led the Brazilian congress to pass a new electoral law on September 2015 that further limited campaign spending in future elections. ${ }^{5}$

\footnotetext{
${ }^{4}$ See Ferraz and Finan (2011) for institutional details on Brazil's local politics.

${ }^{5}$ See http://www.planalto.gov.br/ccivil_03/_ato2015-2018/2015/lei/113165.htm.
} 
It established a cap on the amount candidates could spend on their campaigns. The law states that candidates running for mayor are limited to spend the maximum of either $\mathrm{R} \$ 100,000$ (approximately $\$ 30,000$ ) or $70 \%$ of the highest amount spent by a candidate in the same municipality in the previous election. As stated, the law creates a kink in the amount that candidates can spend at around $\mathrm{R} \$ 142,858$ as $70 \%$ of $\mathrm{R} \$ 142,858$ is $\mathrm{R} \$ 100,000.6$. Thus for any value lower than $\mathrm{R} \$ 142,858$ the cap is given by $\mathrm{R} \$ 100,000$ while for higher values the cap is given by $70 \%$ of the largest value spent in the previous election.

The law also determined that the caps set by the $70 \%$ rule and disclosed in December 2015 should be adjusted by the accumulated inflation between the 2012 and 2016 elections (see Figure 1 for a timeline of the events leading up the 2016 elections). For municipalities capped at $\mathrm{R} \$ 100,000$, they increased the limit by 8.04 percent, which corresponds to the increase in the INPC price index between October 2015 (the month the law was issued) and October 2016. For municipalities capped at 70 percent of the maximum amount spent in the 2012 election, the cap was adjusted by 33.7 percent, which corresponds to the increase in the price index that took place between October 2012 and June 2016. As a result, the inflation-adjusted caps created a discontinuous kink in the campaign spending limits of about 25 percent, which is what our research design will exploit (see Figure 2). ${ }^{6}$

\subsection{Data}

The data used here come from two sources. The election data come from Brazil's Electoral Commission (TSE). We complement these data with information from the 2010 population census, aggregated at the municipality level. The census data include basic demographic and socio-economic characteristics of the municipality, such as: population size, average income, literary rates, share of the urban population.

The electoral data in Brazil is unusually rich. The data we use in the analysis covers all candidates that ran for mayor in 2012 and 2016. In addition to their election results, for each candidate we know a basic set demographic characteristics, such as their gender, age, education level, and self-reported wealth, as well as their campaign contributions and expenditures. Based on this information, we compute at the municipal level, our main political outcomes: campaign spending, the number of candidates that ran for mayor, characteristics of the candidate pool, and re-election

\footnotetext{
${ }^{6}$ The information on the spending caps is publicly available and can be assessed at the Electoral Court webpage at: http://www.tse.jus.br/eleicoes/eleicoes-2016/prestacao-de-contas/divulgacao-dos-limites-legais-de-campanha.
} 
rates.

The final analysis sample includes information on Brazil's 5,562 municipalities over the 2012 and 2016 elections. Descriptive statistics for the 2016 elections appear in Table 1. On average, elections for mayor attract 3 candidates. Only 13 percent of candidates are female, and only 50 percent of candidates have a college degree. The average candidate in a municipality self-declares asset holdings of about $\mathrm{R} \$ 1,000,000$, but this number masks a lot of heterogeneity as the maximum amount self declared by a candidate in a municipality ranges from $\mathrm{R} \$ 43,600$ to $\mathrm{R} \$ 24.2$ million.

In Brazil, incumbents do not enjoy the much of an incumbency advantage. In fact, conditional on running for reelection, incumbents were only re-elected in 48.2 percent of municipalities, and received on average 46.8 percent of the votes.

\section{Model}

Our model builds on the extensive literature studying contests and all-pay auctions in the context of political lobbying and campaigning. In our framework, we extend the $n$-player contest model with generalized technologies of Cornes and Hartley (2005) by incorporating bid caps and a representative voter into the model. ${ }^{7}$

Suppose there is a representative voter and there are $n \geq 2$ potential candidates running for election. The set of candidates is denoted by $N$ and we index candidates by $i$. The timing of the game is as follows. First, each candidate simultaneously chooses a non-negative level of campaign expenditures $x_{i}$. After the expenditure choices are made, but before the voter makes his choice, a taste shock $\xi_{i}$ is drawn from a type I extreme-value distribution. Finally, the voter selects his preferred candidate. In this section, we will solve for the game's unique subgame perfect Nash equilibrium and derive comparative statics to study the effects of bid caps on equilibrium behavior.

We assume that campaign spending makes candidates more appealing to voters, but with diminishing returns. Thus, the voter's utility from selecting candidate $i$ is strictly increasing and strictly concave in the candidate's expenditures $x_{i}$. We do not explicitly model why campaign spending is persuasive to the voter and leave the mechanism as a black box. The voter also derives utility from the candidate's quality $\delta_{i}$. The quality of the candidate captures all factors other than campaign

\footnotetext{
${ }^{7}$ The contest model without bid caps has also notably been studied by Stein (2002), Siegel (2009), and Franke et al. (2013). The contest model has also been extended to consider the effect of public campaign spending laws (Klumpp et al., 2015).
} 
expenditures and the pre-electoral taste shock which affect the voter's valuation of a candidate. For instance, these factors may include the valence of the candidate or an incumbency advantage. Thus, the voter's utility from selecting candidate $i$ is

$$
v_{i}=\delta_{i}+\gamma \log x_{i}+\xi_{i}
$$

where $\gamma$ denotes the effectiveness of a candidate's expenditures. Because $\xi_{i}$ are independently drawn from a type I extreme-value distribution, it follows that the probability that candidate $i$ wins the election is given by:

$$
p_{i}(\mathbf{x})=\frac{a_{i} x_{i}^{\gamma}}{\sum_{j=1}^{N} a_{j} x_{j}^{\gamma}}
$$

where $\mathbf{x}$ is the vector of campaign expenditures, and $i$ 's quality is parametrized by $a_{i}:=\exp \left(\delta_{i}\right)$.

We normalize the benefit from winning the election to 1 . We assume that candidates may differ in the cost of expenditures, such that candidate $i$ 's marginal cost of spending is $c_{i}$. Differences in the marginal cost may reflect differences in the capacities of candidates to raise funds or proxy for differences in wealth for self-financing candidates. The utility function of candidate $i$ as a function of expenditures is given by:

$$
u_{i}(\mathbf{x})=p_{i}(\mathbf{x})-c_{i} x_{i}
$$

All candidates have a common spending limit $\bar{x}$. Since, expenditures must also be nonnegative, the candidate's maximization problem is:

$$
\max _{x_{i}} p_{i}(\mathbf{x})-c_{i} x_{i} \quad \text { s. t. } \quad 0 \leq x_{i} \leq \bar{x}
$$

We define the input of candidate $i$ to be $y_{i}:=a_{i} x_{i}^{\gamma}$, which will be useful to simplify notation. We henceforth assume that $\gamma=1$ so that expenditures have constant returns to scale in the production of inputs in the contest function.

We now solve the maximization problem (4). Candidate $i$ 's best response input choice $b_{i}$ to the aggregate input $\tilde{Y}_{i}:=\sum_{j \neq i} y_{j}$ of other candidates is given by:

$$
b_{i}\left(\tilde{Y}_{i}\right)=\min \left\{\max \left\{\sqrt{\frac{a_{i}}{c_{i}}} \tilde{Y}_{i}-\tilde{Y}_{i}, 0\right\}, a_{i} \bar{x}\right\}
$$

Define the share function $s_{i}(Y):=1-\tilde{Y}_{i} / Y$ to be the share of inputs by candidate $i$ when playing a best response to $\tilde{Y}_{i}$. In our setting, a candidate's share of inputs is also his probability of winning 
the election. From equation (5), it follow that:

$$
s_{i}(Y)=\min \left\{\max \left\{1-\frac{c_{i} Y}{a_{i}}, 0\right\}, \frac{a_{i} \bar{x}}{Y}\right\}
$$

Let $S(Y)=\sum_{i} s_{i}(Y)$ denote the sum of the individual shares when total inputs are $Y$. This function is greater than 1 for sufficiently small values of $Y$, equal to zero for sufficiently large values of $Y$, strictly decreasing whenever positive, and continuous. Thus, there is a unique $Y^{*}$ where $S\left(Y^{*}\right)=1$, which is the pure strategy Nash equilibrium outcome. ${ }^{8}$

Proposition 1. There is a unique pure strategy subgame perfect Nash equilibrium.

We refer to the candidates with strictly positive equilibrium expenditures as entrants and denote the set of entrants by $M$. Note that in equilibrium, there must be no less than two entrants. An equilibrium with one entrant is impossible as the entrant would prefer to reduce spending, and an equilibrium with no entrants cannot occur as any candidate would have the incentive to enter.

There are two types of entrants. There are those who spend at the cap and those who spend strictly less than the cap. We refer to these respectively as the binding and non-binding entrants. We denote the set of binding entrants by $B$ and the set of non-binding entrants by $N B$. There are three types of equilibria, depending on whether all entrants are binding, all entrants are non-binding, or there are both binding and non-binding entrants.

By summing over equation (6), we solve for each candidate's strategy in equilibrium $x_{i}^{*}$ in terms of the model's primitives:

$$
x_{i}^{*}=\min \left\{\max \left\{\frac{Y^{*}}{a_{i}}\left(1-\frac{c_{i} Y^{*}}{a_{i}}\right), 0\right\}, \bar{x}\right\}
$$

where

$$
Y^{*}= \begin{cases}\frac{k-1+\sqrt{(k-1)^{2}+4 \bar{x} \sum_{j \in B} a_{j} \sum_{j \in N B} \frac{c_{j}}{a_{j}}}}{2\left(\sum_{j \in N B} \frac{c_{j}}{a_{j}}\right)} & \text { if } N B \text { is nonempty } \\ \bar{x} \sum_{i \in M} \alpha_{i} & \text { otherwise. }\end{cases}
$$

\footnotetext{
${ }^{8}$ This argument, with the use of share functions, was first used by Cornes and Hartley (2005) to show the existence of a unique pure strategy Nash equilibrium in the setting without spending caps.
} 
and

$$
\begin{aligned}
M & =\left\{i \in N: \frac{a_{i}}{c_{i}}>Y^{*}\right\} \\
N B & =\left\{i \in M: a_{i} \bar{x}>Y^{*}\left(1-\frac{c_{i} Y^{*}}{a_{i}}\right)\right\} \\
B & =\{i \in M: i \notin K\}
\end{aligned}
$$

and $k:=|N B|$ is the number of non-binding entrants. Recall that $M$ denotes the set of entrants, $N B$ the subset of entrants who spend less than the cap, and $B$ the subset of entrants who spend at the cap. Let $m:=|M|$ denote the number of entrants. We next analyze the effects of the spending cap $\bar{x}$ on equilibrium outcomes.

Proposition 2. (The effects of spending limits.)

(a) If all candidates are symmetric with respect to quality, i.e. if $a_{i}=a \forall i$ for some $a>0$, then equilibrium total expenditures increase in the spending limit. However, equilibrium total expenditures need not increase if candidates are asymmetric with respect to quality.

(b) The number of entrants in equilibrium decreases in the spending limit.

(c) The average ability of entrants is increasing in the spending limit if the marginal cost is constant across candidates. Moreover, the average marginal cost of expenditures of entrants is decreasing in the spending limit if ability is constant across candidates.

(d) Holding constant the entrant pool, a candidate's equilibrium probability of election

(i) is unchanged by an increase in the spending limit if all entrants spend at the cap or if all entrants spend less than the cap;

(ii) decreases in the spending limit if the candidate spends less than the cap and at least one other candidate spends at the cap;

(iii) increases in the spending limit if the candidate spends at the cap and at least one other candidate spends less than the cap.

Proof. See the appendix.

Part (a) of Proposition 2 states that total expenditures are not necessarily higher with larger spending caps when ability differs between entrants. This result is an extension to previous findings in 
the literature studying contests and all-pay auctions in the context of political lobbying. ${ }^{9}$ To understand the intuition behind this result, consider a situation where there are two high-ability entrants spending at the cap and a low-ability entrant spending less than the cap. It is then possible that the non-binding entrant reduces his spending at a greater rate than the rate at which binding entrants increase their expenditures when the spending limit increases.

Parts (b) and (c) refer to the effects of spending limits on the size and composition of the entrant pool. We find that increases in the spending cap may only decrease the number of entrants. Intuitively, this is because in equilibrium, while total spending is not necessarily increasing in the spending cap, total inputs are. Thus, with higher spending limits, elections are more competitive in the sense that a candidate must make larger expenditures to achieve the same probability of winning. On the other hand, the candidate's valuation of the office and his marginal cost of spending are unchanged with higher limits, and hence he is less likely to enter.

An increase in the spending limit will also have effects on the composition of the pool of entrants. By equation (9), we see that the threshold to entry depends on the ratio of the candidate's quality $a_{i}$ to the marginal cost of spending $c_{i}$. As the spending cap is increased, the entrants with the lowest ratios will exit first. This has two implications. First, if costs are symmetric across candidates, then higher spending limits will create an entrant pool composed of higher quality candidates. Recall that by quality, we refer to all factors that make a candidate more desirable to the voter other than spending and the pre-electoral taste shock. In this sense, only the more electable candidates will choose to run when limits are generous. Second, if ability is symmetric across candidates, then increasing the spending limit will cause the candidates with the highest marginal cost of spending to drop out of the race. Interpreting the cost of expenditures as a proxy for the wealth or fundraising capability of a candidate, then we would expect the entrant pool to be wealthier and more strongly connected to potential donors when spending caps are high.

Finally, in part (d) of Proposition 2, we show that an increase in the spending limit may increase, reduce, or have no effect on an entrant's probability of election. The main finding is intuitive: entrants who are spending at the cap (weakly) benefit from increases in the cap, whereas entrants who spend less than the cap are (weakly) harmed. Thus, in order to understand the effect of spending

\footnotetext{
${ }^{9}$ In both types of games, each player chooses a positive bid and must pay its cost whether or not the player wins. In all-pay auctions, the winner is the player with the highest bid, whereas in the contest the probability of winning is increasing in one own's bid and decreasing in others' bids. Che and Gale (1998) consider a two-player all-pay auction and show that bid caps may increase total expenditures. On the other hand, considering an $n$-player contest, Fang (2002) finds that imposing an exogenous cap never increases total expenditures. In contrast to Fang (2002), our model also allows bidders to differ in their abilities to convert expenditures into inputs in the contest function, and hence we find that bid caps may have either effect in the $n$-player contest.
} 
limits on the incumbency advantage, it is crucial to determine whether incumbents are more likely to be binding or non-binding spenders.

\section{Research Design}

We are interested in estimating the causal effects of campaign spending limits on political entry and selection. As we discussed in Section 2, prior to the 2016 municipal elections the Brazilian government imposed a cap on the amount of money a candidate could spend in the election. The law created a discontinuous kink in the spending cap for municipalities with a candidate that spent above $\mathrm{R} \$ 142,857$ in the 2012 elections.

Visually, the effects of the law on candidate spending for the 2016 elections are quite clear in Figure 3. For municipalities that did not have a 2012 candidate who spent above R $\$ 142,857$, their candidates were capped at $\mathrm{R} \$ 108,039$. For the municipalities above this threshold, the spending cap jumps up by about 25 percent and then increases linearly as determined by the rule. It is also clear from Figure 3 that the caps were not binding for the majority of the municipalities. As a result, one should interpret our findings as an intention-to-treat estimates.

To identify the effects of spending limits, we exploit the discontinuity at $\mathrm{R} \$ 142,857$ using a standard regression discontinuity design approach. Let $S_{m, 2012}$ denote the maximum amount spent by a candidate in municipality $m$ during the 2012 elections. The treatment effect on outcome $Y_{m, 2016}$ of the spending cap is given by

$$
\text { Treatment Effect }=\lim _{s \downarrow 142,857} E\left[Y_{m, 2016} \mid S_{m, 2012}=s\right]-\lim _{s \uparrow 142,857} E\left[Y_{m, 2016} \mid S_{m, 2012}=s\right] .
$$

The first conditional expectation measures the expected outcome at the threshold for municipalities in which candidates' campaign spending is capped at $\mathrm{R} \$ 133,700$. The second conditional expectation function measures the expected outcome at the threshold for municipalities in which candidates' campaign spending is capped at $\mathrm{R} \$ 108,039$. Under the assumption that these two conditional expectations are continuous in $s$, this difference estimates at the point of discontinuity, the causal effect of campaign spending limits on our political outcomes.

We estimate these conditional expectations by local linear regression using only data within a bandwidth $h$ of the threshold. Formally, we estimate the following OLS model, for $S_{m, 2012} \in$ 
$(142,857-h, 142,857+h)$

$$
Y_{m, 2016}=\alpha+\beta \mathbb{1}\left\{S_{m, 2012}>142,857\right\}+\delta_{0} S_{m, 2012}+\delta_{1} S_{m, 2012} \mathbb{1}\left\{S_{m, 2012}>142,857\right\}+\varepsilon_{m, 2016}
$$

where $\mathbb{1}\left\{S_{m, 2012}>142,857\right\}$ is an indicator equal to 1 when $S_{m, 2012}>142,857$, and $\varepsilon_{m, 2016}$ represents the error term. The parameter $\beta$ measures the treatment effect. For our choice of bandwidth $h$, we rely on the approach developed by Calonico et al. (2014). This optimal bandwidth choice is a function of the data and is thus different for each outcome, $Y_{m, 2016}$. We also explore the robustness of our results to alternative bandwidth sizes.

Before presenting our results, it is important to test the validity of our research design. In Panel (a) of Figure 4 we plot the density of our "running variable", $S_{m, 2012}$. Unsurprisingly, we do not find any evidence of manipulation or endogenous sorting around the discontinuity threshold. This is completely expected: campaign expenditures are made public immediately following each election, and no one could have anticipated the recent law change back in 2012. As a point of comparison, Panel (b) of Figure 4 plots the distribution of campaign spending for the 2016 election. In contrast to the previous plot, panel (b) does exhibit substantial bunching at the spending cap of $\mathrm{R} \$ 108,039$.

Another general concern associated with regression discontinuity designs is the possibility that other determinants of our outcomes of interest are also varying discontinuously at the cutoff point. Although we cannot directly test this assumption for unobserved characteristics, we can examine whether any observable characteristics of the municipality also exhibit discontinuous jumps at the cutoff point. In Figure 5, we present a series of plots, exploring various municipal characteristics that are correlated with our political outcomes of interest, such as GDP per capita, illiteracy, and the share of the urban population. ${ }^{10}$ In each graph, we plot a bin scatter of the municipal characteristic against the maximum amount a candidate spent in the municipality during the 2012 elections (i.e. our running variable). In addition to these binned averages, we also fit a second-order polynomial on each side of the point of discontinuity and $95 \%$ confidence intervals for each bin. We do not find any evidence of other characteristics jumping at the cutoff point. All the differences are close to zero in magnitude and statistically insignificant. Importantly, these comparisons also include our main political outcomes of interest but measured for the 2012 elections (i.e. the "pre-treatment period").

\footnotetext{
${ }^{10}$ These plots represent only a subset of the characteristics for which we tested. Table 2 presents the entire set. Out of the 18 municipality characteristics tested, only one displayed a discontinuous jump at the cutoff point (population). For this reason, we control for the municipal characteristics measured in the 2010 Census in our analysis.
} 


\section{Results}

\subsection{Effects of Spending Caps on Campaign Expenditures and Contributions}

In this section, we estimate the causal effects of the spending caps on candidates' campaign spending and contributions. We begin with the graphical evidence. In Panel A of Figure 6, we plot binned averages of the amount candidates spent in the 2016 elections against our running variable (the maximum amount spent by a candidate in the 2012 elections centered at $\mathrm{R} \$ 142,857$ ). We also fit a second-order polynomial, separately estimated on each side of the discontinuity. The discontinuity at zero provides an estimate of the gap in candidates' campaign spending imposed by the law. The estimated discontinuity implies that a 25 percent increase in the spending cap increased maximum campaign spending by approximately 12 percent during the 2016 elections for municipalities near the discontinuity. In panel B, we reproduce the graph presented in panel A, but for the mean amount spent by a candidate. We see a similar increase of approximately 10 percent, which further suggests that the caps did bind for many candidates.

We refine the graphical analysis in Table 3. Each row corresponds to a different dependent variable, and each numbered column presents the estimated impact for a different regression specification. In column 1, we present our baseline estimates of Equation 13, using the bandwidth proposed by Calonico et al. (2014). In columns 2 and 3, we explore the robustness of our estimates to different bandwidth choices. In column 4 , we further test the sensitivity of our results by fitting a local quadratic polynomial on each side of the discontinuity instead of a local linear polynomial.

Our results are robust to these various modeling choices. In our baseline specification, the highestspending candidate just to the left of the discontinuity spent on average $\mathrm{R} \$ 84,823$ to become mayor, compared to $\mathrm{R} \$ 95,036$ for candidates in municipalities just to the right of the discontinuity. This represents a 12.0 percent increase in spending. The point estimates in columns 2-4 are similar: they indicate increases in maximum spending ranging from 11.6 to 13.9 percent. The estimates on average spending, although a bit noisier, are also consistent across specifications. They imply that the higher spending cap led to increases in mean spending ranging from 8.5 to 11.7 percent.

The theory does not provide clear predictions on the effects of a spending cap on the minimum or total amount spent in an election. In some cases, a higher spending cap will induce the minimumspending candidate to reduce spending further, or even exit the race. Thus increasing the spending cap does not necessarily lead to an increase in the minimum or total spending within a race. Consistent with the theory, we do not find significant effects on either of these two outcomes. The 
minimum amount spent by a candidate is similar on both sides of the point of discontinuity: we estimate a statistically insignificant increase of $\mathrm{R} \$ 989$. Similarly, we also find a statistically insignificant increase in total spending of about 4 percent at the cutoff point.

In Table 4, we consider the effects of spending caps on the amount and composition of candidate campaign contributions. On average, candidates spend $99 \%$ of their campaign contributions. ${ }^{11}$ Reflecting our findings on spending, we find that the average amount of campaign contributions raised by candidates are $\mathrm{R} \$ 6,179$ higher for municipalities with the higher limit. Approximately $75 \%$ of this increase comes in the form of candidates financing their own campaigns, which likely stems from the law's ban on corporate donations. In 2012, candidates received on average 16 percent of their contributions from corporations, and self-financed 25 percent of their campaigns. In contrast, 2016 candidates self-financed 40 percent of their campaign expenditures. We can interpret these results in two ways. On the one hand, in the face of the corporate ban, the higher caps induced the existing candidates to contribute more to their own campaigns. On the other hand, higher caps may have attracted a wealthier pool of candidates with greater financial means to run for office. We examine this possibility in the next section.

\subsection{Effects of Spending Caps on Candidate Entry}

According to our model of candidate entry, the number of candidates who enter the race should decrease as spending limits increase. Additionally, higher spending limits may also attract individuals who have a higher ex-ante probability of winning. We test these predictions in Table 5. As before, the rows indicate different dependent variables, and the numbered columns present the estimated effects of the caps for different modeling choices.

Spending caps affect the entry decisions of potential candidates. Compared to the municipalities just to the right of the threshold (i.e. the less constrained municipalities), the cap led to a 0.26 increase in the number of candidates for municipalities capped at $\mathrm{R} \$ 108,039$. On average, 2.9 candidates run for mayor, so this effect represents a 9 percent increase in the size of the candidate pool. This result is presented visually in Figure 7. In contrast to the plot presented in panel C of Figure 5, which displayed the effects on the number of candidates who participated in the 2012 elections, we see a significant jump in the number candidates at the point of discontinuity.

To test whether this increase in candidate entry actually increased political competition, we study the effect of the cap on the effective number of candidates. This measure is computed by taking

\footnotetext{
${ }^{11}$ In Brazil, candidates are not allowed to accumulate war chests.
} 
the inverse of the sum of squared vote shares of each running candidate within an electoral race. Thus, if all candidates have the same vote share, then this measure is equal to the actual number of candidates. At the other extreme, if one candidate wins every vote, then the effective number of candidates is one. If a change in the spending cap only leads to the entry or exit of candidates winning few or no votes, then we would not find an effect on the effective number of candidates. On the contrary, we find that the more restrictive spending cap increases the effective number of candidates by 0.143 , suggesting that the restrictive cap did increase the competitiveness of mayoral races.

To examine whether higher spending limits also induce greater participation from individuals with a higher ex-ante propensity to get elected, we first estimate the probability of winning the 2016 election based on the follow set of observable characteristics: gender, age, race, education level, political experience, party affiliation and self-reported assets. We estimate this propensity score for the sample of candidates that are outside the bandwidth of the RD regressions. The results, which are reported in Table A.1, suggest that candidates who are male, wealthier, incumbents, or have more political experience are more likely to win. Based on these estimates, we then impute a candidate's ex-ante probability of winning the election.

We find that individuals with higher expected winning probabilities are more likely to participate in municipalities with a higher spending limit. For a 25 percent increase in the spending limits, high-propensity types are 2.0 percentage points more likely to enter, which represents a 6 percent increase.

To see where these effects are coming from, in the remaining rows, we estimate the effects on individual attributes of the candidate pool. Although the estimates tend to be fairly noisy across the various attributes, higher limits do appear to affect an important factor: they tend to attract wealthier candidates. In our baseline specification, the average level of assets among candidates is 40 percent higher in municipalities with a higher spending cap. This result is perhaps unsurprising given our finding that the majority of the extra spending under the high-cap is self-funded. Interestingly, we do not find that the higher spending cap significantly affected the share of candidates from small parties to enter the race. ${ }^{12}$

\footnotetext{
${ }^{12}$ We define the "small" parties to be all political parties except for the six most successful in the 2012 municipal elections: the PMDB, PP, PSB, PDB, PSDB and PT. Together, these six parties won the majority of mayoral elections in 2012. In total, there are thus 30 small parties in the 2016 elections. Our results are robust to the choice of party classification.
} 


\subsection{Effects of Spending Caps on Political Selection}

While restricting campaign spending does increase political competition, it appears to do so at the cost of attracting individuals with a lower ex-ante propensity to be elected. Whether spending caps affect political selection is therefore an empirical question.

The graphical evidence presented in Figure 8 suggest that it does. Here, we plot binned averages of re-election rates against the maximum amount spent in the municipality by a candidate for the 2012 elections. In computing this graph, we restrict the sample to the 2,721 incumbents who were eligible for re-election. We see a positive jump in the reelection rate at the point of discontinuity.

In Table 6 we refine the analysis further, by considering a range of alternative specifications and by conditioning on whether or not the mayor ran for re-election. In Panel A we consider all incumbents who are not term-limited, whereas in Panel B we consider only those who run for re-election. When considering the whole sample of eligible incumbents, re-election rates increase by 11 percentage points at the point of discontinuity, which is a sizable effect given that the baseline re-election rate is only 23 percent. Among those that ran for re-election, the effects are similar: we estimate a 16 percentage point increase in the re-election rate from a baseline of 38 percent. To further analyze whether incumbents benefit from the higher cap, we test whether incumbents see their vote shares increase or decrease as a function of the cap. We find that incumbent vote shares increase by 6.6 percentage points under the higher cap.

Considering the apparent incumbency advantage granted by the higher spending cap, it is plausible that more incumbents choose to run for re-election under the high cap. However, due to the late timing of the final announcement on the spending cap, it is unlikely that incumbents conditioned their running decision on the cap. Indeed, we do not find any evidence that incumbents are more likely to run for re-election in places with higher spending limits. However, the standard errors are admittedly quite large, and thus we cannot rule out meaningful effect sizes.

Why do incumbents benefit from the higher spending limit? According to the model, if the candidates are symmetric with respect to valence, then a candidate's probability of winning increases if his share of spending within the race increases. If fewer challengers enter the race, or if the existing challengers are unable to increase spending at the same rate as the incumbent due to a higher marginal cost of raising funds, then the higher cap will increase the incumbent's spending share. We test whether this is the case in the data. We find that incumbent spending increases significantly by $\mathrm{R} \$ 10,312$ under the high spending cap. On the other hand, total challenger spending hardly increases by a statistically insignificant $\mathrm{R} \$ 1,108$. Thus, we find evidence that the incum- 
bents' spending shares increase under the higher limit, which likely increases their probability of re-election.

In Table 7, we explore whether the spending caps also affect the characteristics of the winner. Other than being an incumbent, we do not find much evidence that the caps changed the identity of the winner. The one exception is that there is some evidence that the caps led to the election of wealthier candidates (at the $90 \%$ significance level). Interestingly, the spending caps also did not impact the likelihood that a mayor from the Workers' Party (PT) won, despite the party experiencing sweeping losses in local elections throughout the country due to its involvement in the corruption scandal.

Finally, in Table 8, we investigate the effects of the spending caps on the contributions of the winning candidates. We find that the winners under the high cap raised more campaign funds on average than those under the low cap. Moreover, our results suggest that the entirety of this difference is explained by the difference in the amount of funds that candidates self-finance. Indeed, we do not find evidence that winners under the high cap have raised more individual, party, or other donations. Thus, together with our evidence of the effect of caps on candidate assets, our results suggest that high spending limits benefit wealthier candidates, who spend their own funds to get elected.

Do higher spending caps lead to more voter knowledge? A key argument against imposing spending caps is that with less spending, voters may become less informed. In Table 9 we test for this possibility by estimating the effects of spending caps on turnout and the share of blank or invalid votes. Although these are imperfect proxies for voter information, several studies have documented a strong association between political knowledge and both turnout and invalid votes (e.g. Lassen (2005)). Overall, we find no evidence to support the hypothesis that lower spending caps will lead to less informed voters. In both cases, our estimates are precisely estimated zeros.

\section{Conclusion}

The role of money in politics is widely debated in many democracies. This paper examines the effects of limiting how much money candidates can spend on their campaigns. We exploit a natural experiment induced by an electoral reform in Brazil that set a larger cap of spending for some municipalities compared to others. Using data on number of candidates, their characteristics, and voting outcomes we find that setting a more stringent limit on campaign spending increases political competition, reduces the chances of richer candidates getting elected, and reduces incumbency 
advantage.

These findings suggest that, in countries where large spending has become an equilibrium outcome due to corruption and the influence of special interests, setting a spending limit might increase political competition and allow for new entrants into politics. In countries where political elites come disproportionately from richer families, this policy might also reduce the concentration of political power in the hands of richer individuals. These effects might have direct and indirect consequences for policy outcomes.

The establishment of spending limits, by reducing the cost of political campaigns, might reduce the incentives faced by incumbent politicians to divert resources from public funds for their campaigns. Whether campaign spending limits reduce corruption or affect project choices by elected politicians are important topics for future research. 


\section{References}

Ashworth, S. (2006). Campaign Finance and Voter Welfare with Entrenched Incumbents. American Political Science Review, 100(01):55-68.

Austen-Smith, D. (1987). Interest groups, campaign contributions, and probabilistic voting. Public Choice, 54(2):123-139.

Besley, T. and Coate, S. (1997). An economic model of representative democracy. The Quarterly Journal of Economics, 112(1):85-114.

Besley, T., Montalvo, J. G., and Reynal-Querol, M. (2011). Do Educated Leaders Matter? Economic Journal, 121(554):205-205.

Calonico, S., Cattaneo, M. D., and Titiunik, R. (2014). Robust nonparametric confidence intervals for regression-discontinuity designs. Econometrica, 82(6):2295-2326.

Chattopadhyay, R. and Duflo, E. (2004). Women as Policy Makers: Evidence from a Randomized Policy Experiment in India. Econometrica, 72(5):1409-1443.

Che, Y.-K. and Gale, I. L. (1998). Caps on political lobbying. American Economic Review, 88(3):643-651.

Coate, S. (2004). Pareto-improving campaign finance policy. American Economic Review, 94(3):628-655.

Cornes, R. and Hartley, R. (2005). Asymmetric contests with general technologies. Economic theory, 26(4):923-946.

Cotton, C. (2012). Pay-to-play politics: Informational lobbying and contribution limits when money buys access. Journal of Public Economics, 96(3):369-386.

Da Silveira, B. S. and De Mello, J. M. (2011). Campaign advertising and election outcomes: Quasinatural experiment evidence from gubernatorial elections in brazil. The Review of Economic Studies, 78(2):590-612.

Erikson, R. S. and Palfrey, T. R. (2000). Equilibria in campaign spending games: Theory and data. American Political Science Review, 94(3):595-609.

Fang, H. (2002). Lottery versus all-pay auction models of lobbying. Public Choice, 112(3-4):351371. 
Ferraz, C. and Finan, F. (2011). Electoral accountability and corruption: Evidence from the audits of local governments. American Economic Review, 101(4):1274-1311.

Franke, J., Kanzow, C., Leininger, W., and Schwartz, A. (2013). Effort maximization in asymmetric contest games with heterogeneous contestants. Economic Theory, 52(2):589-630.

Gerber, A. (1998). Estimating the effect of campaign spending on senate election outcomes using instrumental variables. American Political Science Review, 92:401-411.

Klumpp, T., Mialon, H. M., and Williams, M. A. (2015). Leveling the playing field? the role of public campaign funding in elections. American law and economics review, 17(2):361-408.

Lassen, D. D. (2005). The effect of information on voter turnout: Evidence from a natural experiment. American Journal of Political Science, 49(1):103-118.

Levitt, S. D. (1994). Using Repeat Challengers to Estimate the Effect of Campaign Spending on Election Outcomes in the U.S. House. Journal of Political Economy, 102(4):777-798.

Milligan, K. and Rekkas, M. (2008). Campaign spending limits, incumbent spending, and election outcomes. Canadian Journal of Economics/Revue canadienne d'économique, 41(4):1351-1374.

Osborne, M. and Slivinski, A. (1996). A model of political competition with citizen-candidates. The Quarterly Journal of Economics, 111(1):65-96.

Pande, R. (2003). Can mandated political representation increase policy influence for disadvantaged minorities? theory and evidence from india. American Economic Review, 93(4):11321151.

Pastine, I. and Pastine, T. (2012). Incumbency advantage and political campaign spending limits. Journal of Public Economics, 96(1):20-32.

Prat, A. (2002). Campaign advertising and voter welfare. Review of Economic Studies, 69(4):999_ 1017.

Prat, A. (2006). Rational voters and political advertising. In Weingast, B. R. and Wittman, D. A., editors, Oxford Handbook of Political Economy. Oxford University Press.

Scarrow, S. E. (2007). Political finance in comparative perspective. Annual Review of Political Science, 10(1):193-210.

Siegel, R. (2009). All-pay contests. Econometrica, 77(1):71-92. 
Speck, B. (2013). Money in politics: Sound political competition and trust in government. Technical report, OECD, Background paper.

Stein, W. E. (2002). Asymmetric rent-seeking with more than two contestants. Public Choice, 113(3-4):325-336.

Stratmann, T. and Aparicio-Castillo, F. J. (2006). Competition policy for elections: Do campaign contribution limits matter? Public Choice, 127(1-2):177-206. 


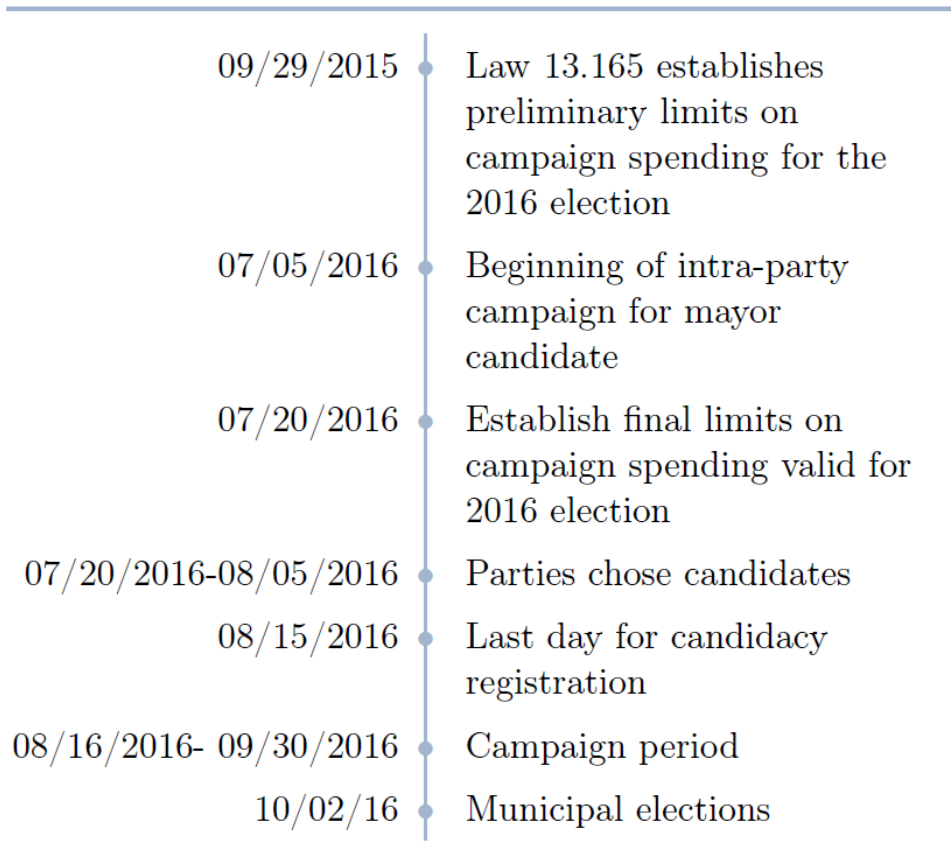

Figure 1: Timeline

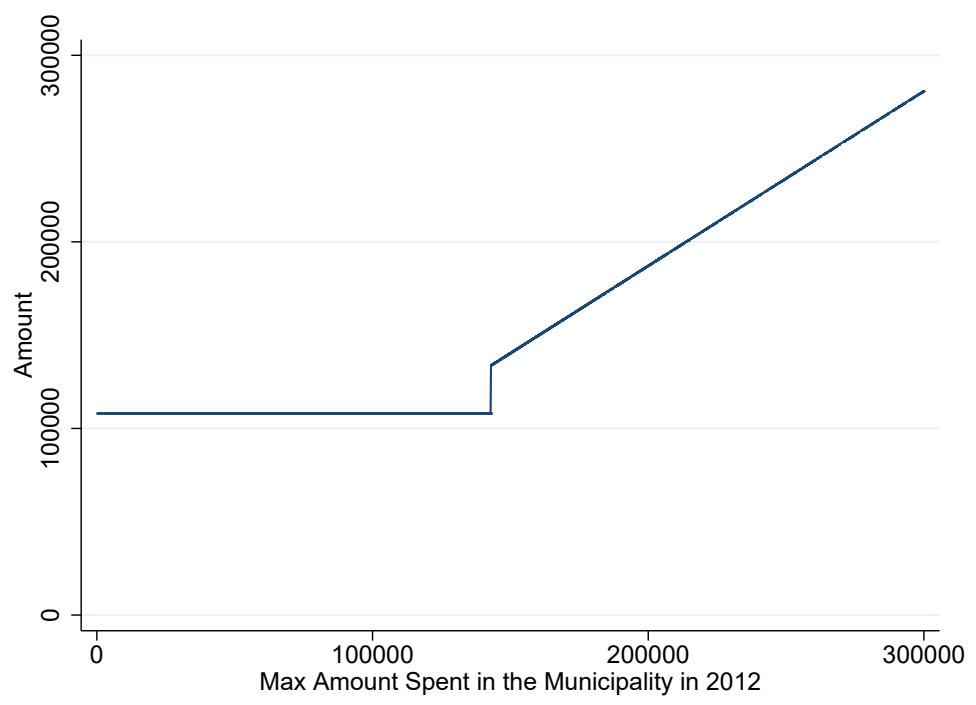

Figure 2: Campaign Spending Limits in 2016 
(a) Candidate spending

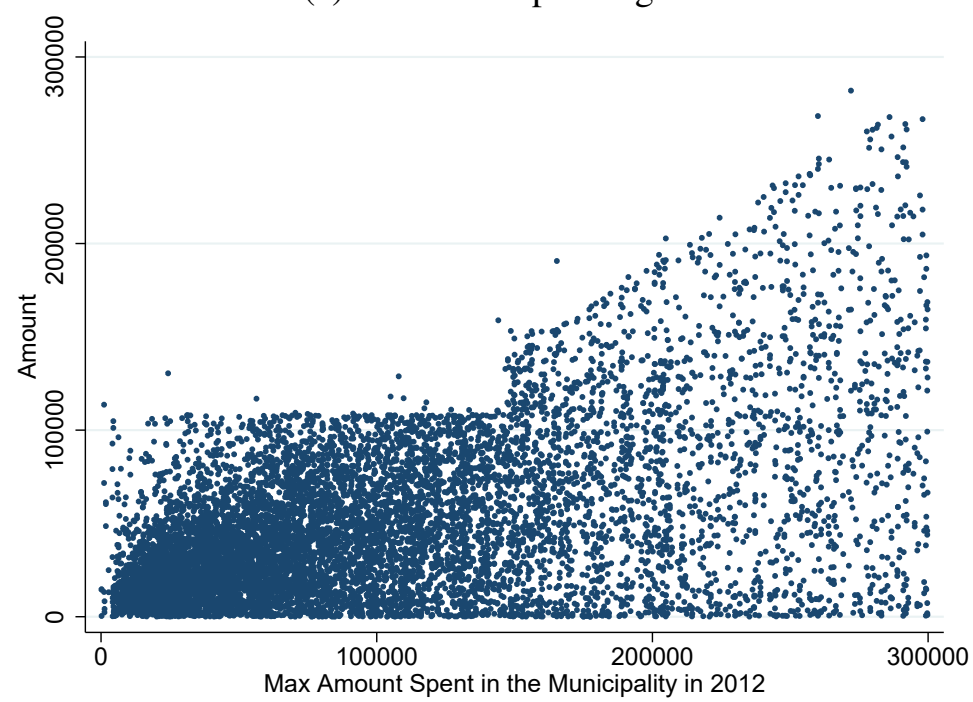

(b) Maximum spending by municipality

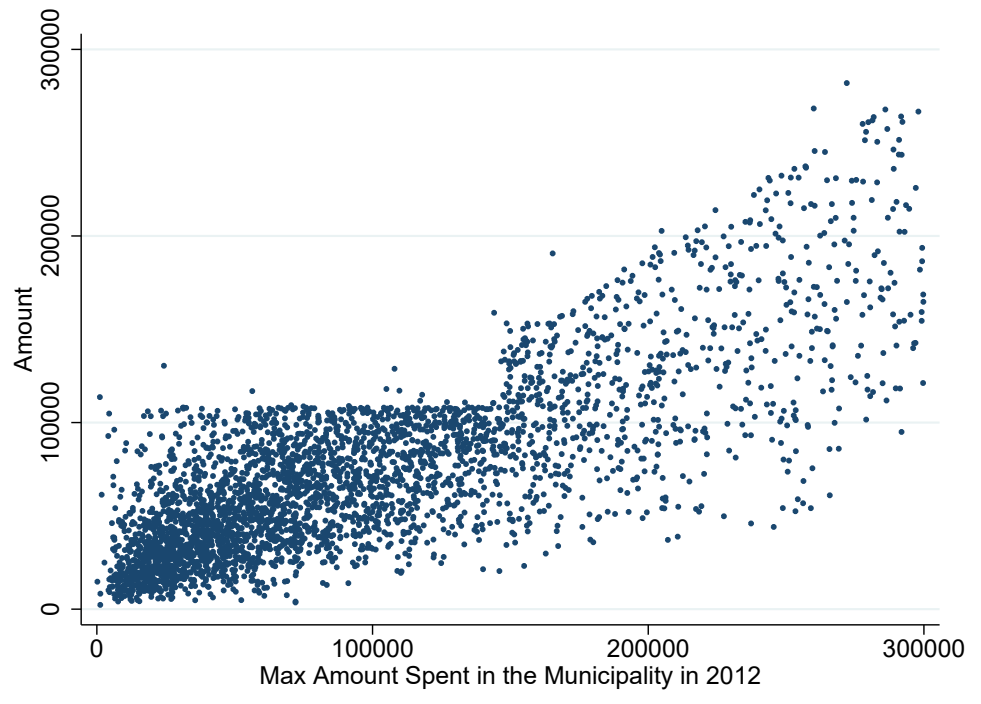

Figure 3: Campaign Spending in the 2016 Elections

Notes: In panel (a), each point denotes the amount spent by a candidate in the 2016 elections. In panel (b), each point denotes the maximum amount spent by a candidate by municipality in the 2016 elections. 
(a) Maximum amount spent in 2012 elections

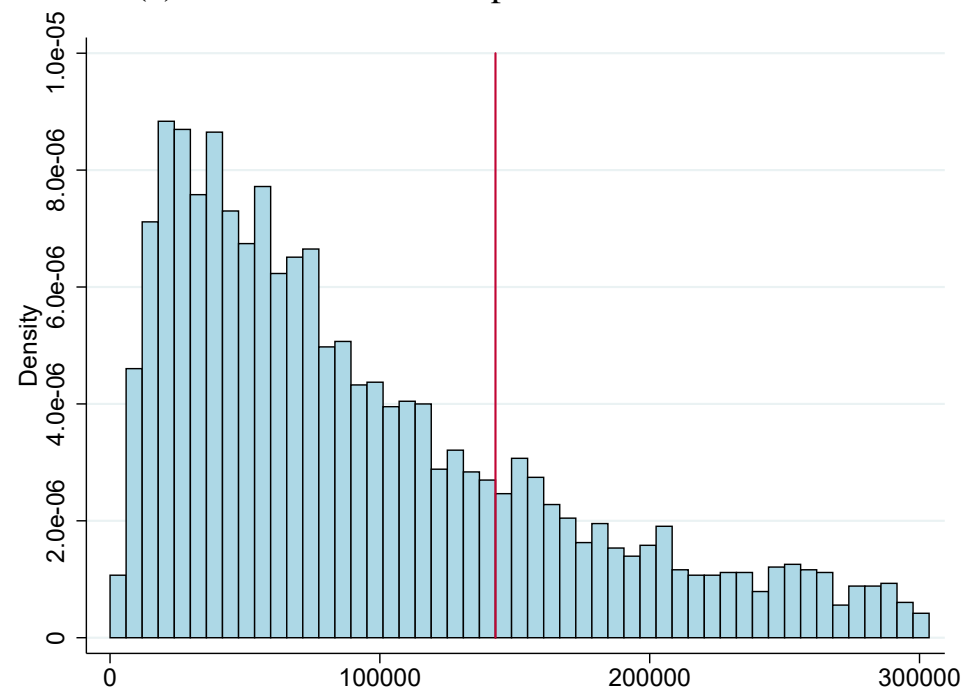

(b) Maximum amount spent in 2016 elections

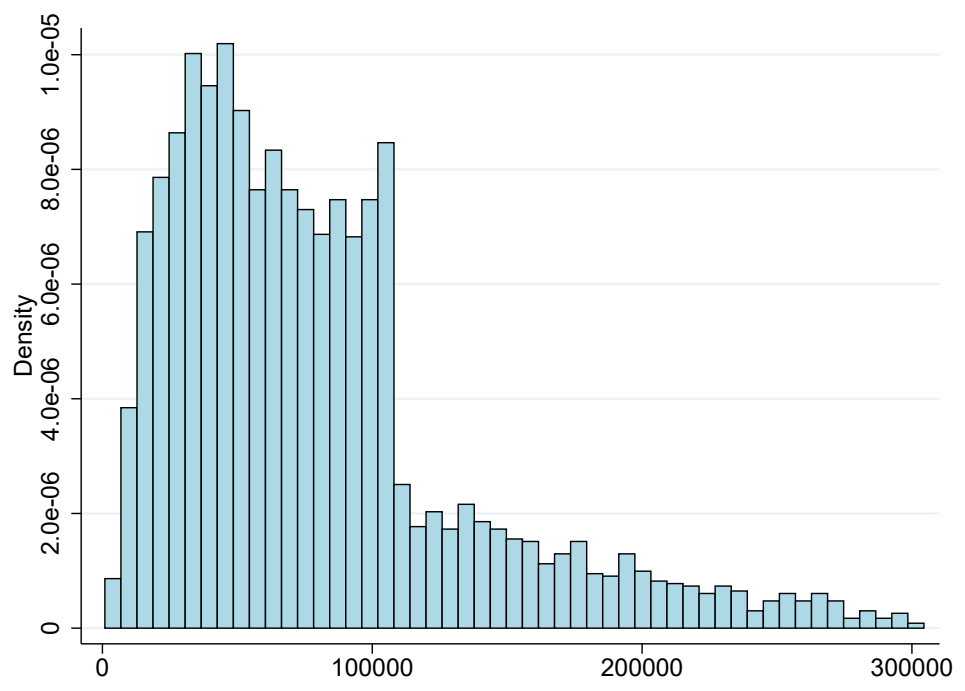

Figure 4: Campaign Spending in the 2012 and 2016 Elections

Notes: Panel (a) plots the distribution of the running variable, the maximum amount spent by a candidate within a municipality in the 2012 elections. The red line denotes the discontinuity of the rule at $\mathrm{R} \$ 142,857$. Panel (b) plots the distribution of the maximum spent on campaigning by a candidate within a municipality in the 2016 elections. 
(a) Mean spending in 2012

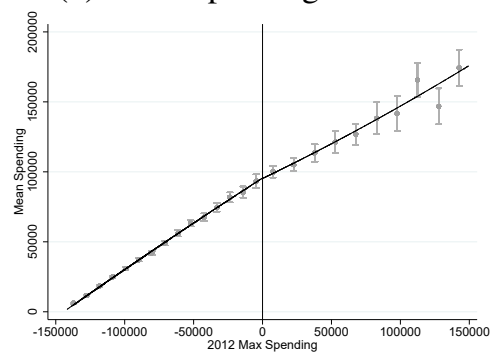

(d) Effective number of candidates

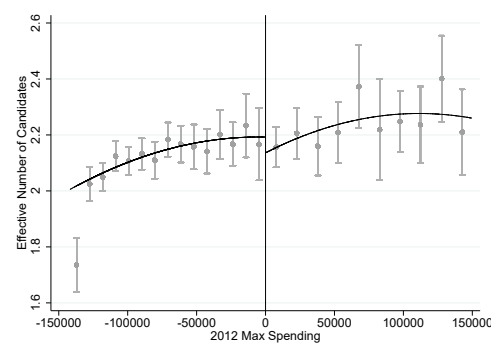

(g) Share urban

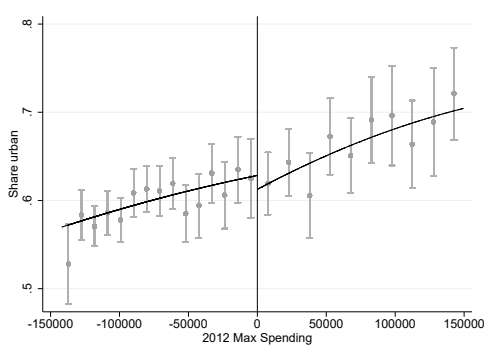

(b) Mean contributions in 2012

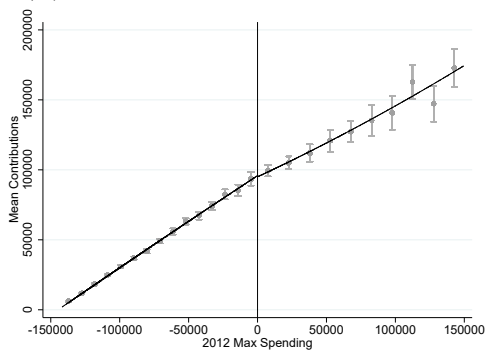

(e) GDP per capita $(\log )$

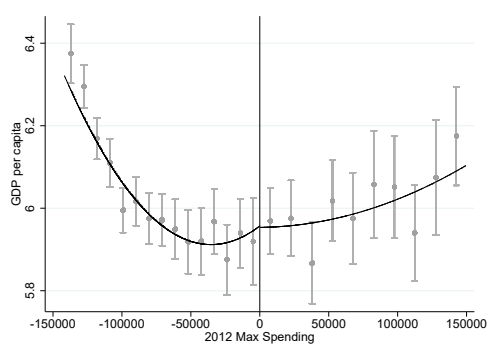

(h) Gini coefficient

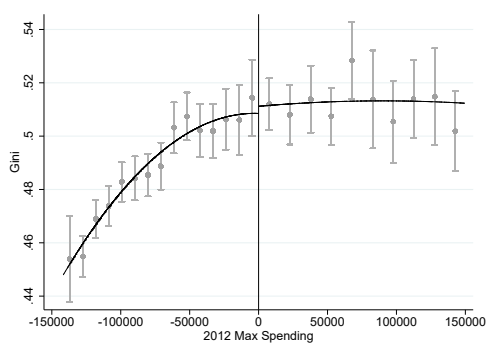

(c) Number of candidates in 2012

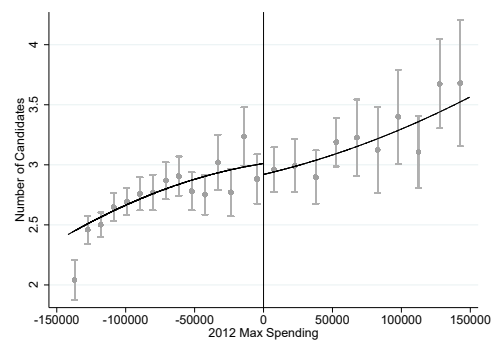

(f) Illiteracy

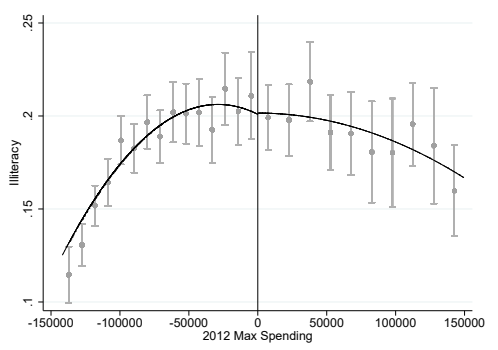

(i) Population $(\log )$

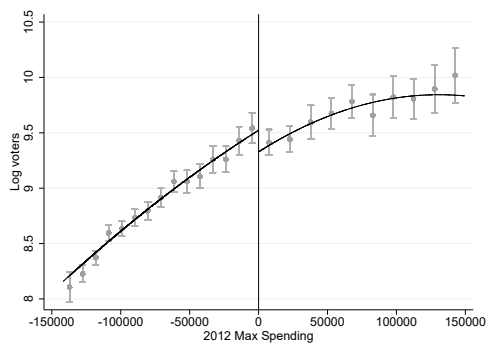

Figure 5: Discontinuities in Municipal-level Baseline Covariates

Notes: These figures plot the results of RD regressions of various municipal characteristics on maximum spending in 2012 (the running variable). The horizontal axis denotes the difference in maximum spending relative to the discontinuity at $\mathrm{R} \$ 142,857$. In each regression, a global second-order polynomial is estimated on each side of the discontinuity. Each point denotes the sample-average within a bin. 95\% confidence intervals for each bin are computed using the methods of Calonico et al. (2014). 
(a) Maximum candidate spending

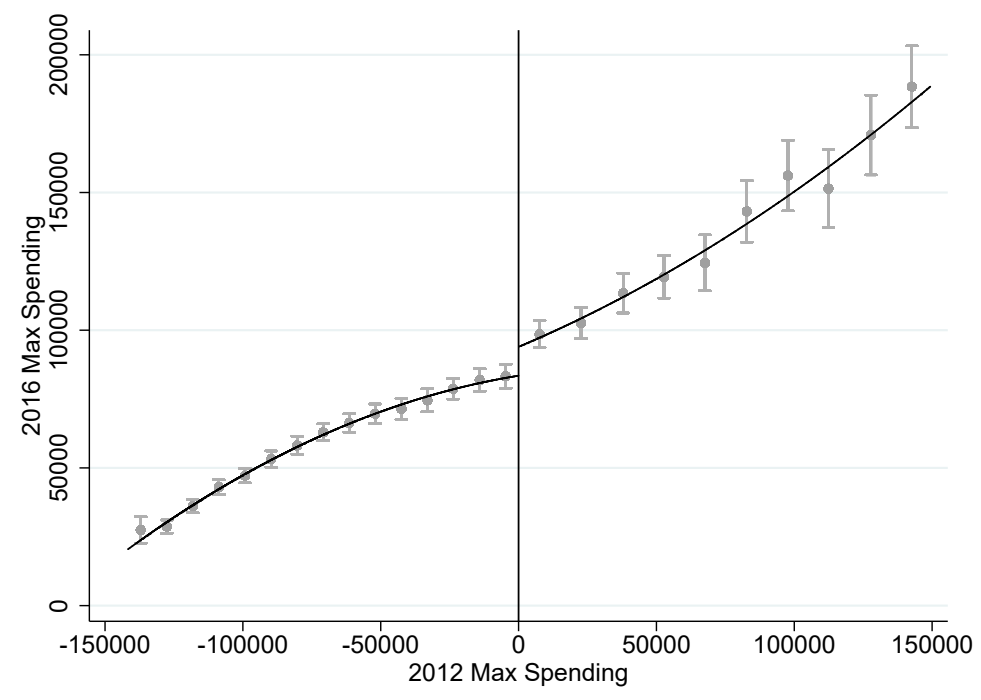

(b) Mean candidate spending

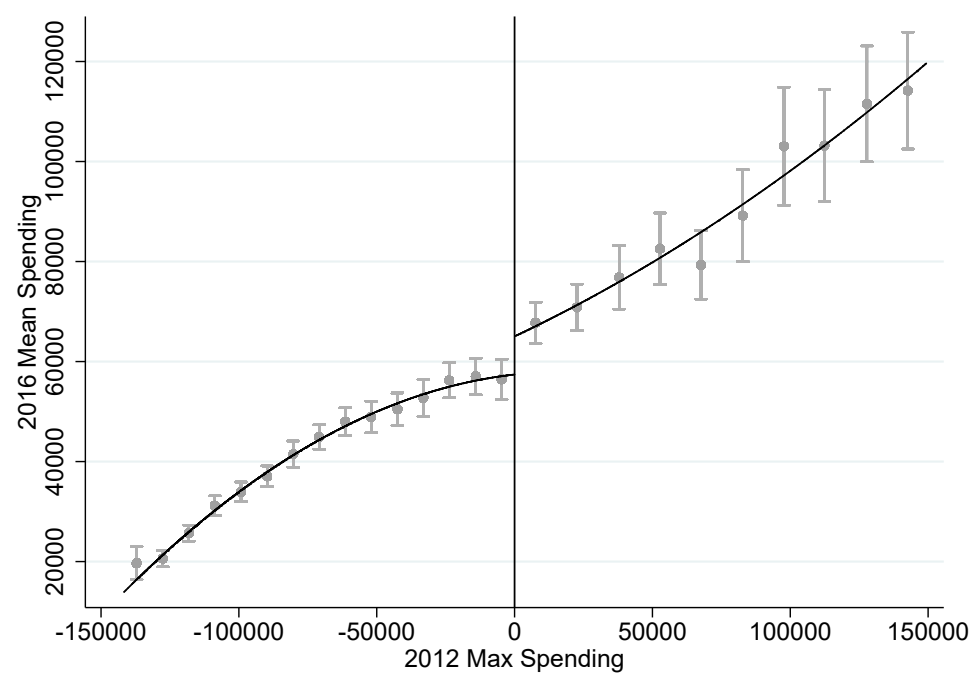

Figure 6: The Effects of Spending Limits on Campaign Expenditures

Notes: This figure plots the results of the regression discontinuity design, where the dependent variable is respectively (a) the maximum spending by candidates and (b) the mean spending by candidates. The horizontal axis denotes the difference in maximum spending relative to the discontinuity at $\mathrm{R} \$ 142,857$. In each regression, a global second-order polynomial is estimated on each side of the discontinuity. Each point denotes the sample-average within a bin and its corresponding $95 \%$ confidence interval. 
(a) Number of candidates

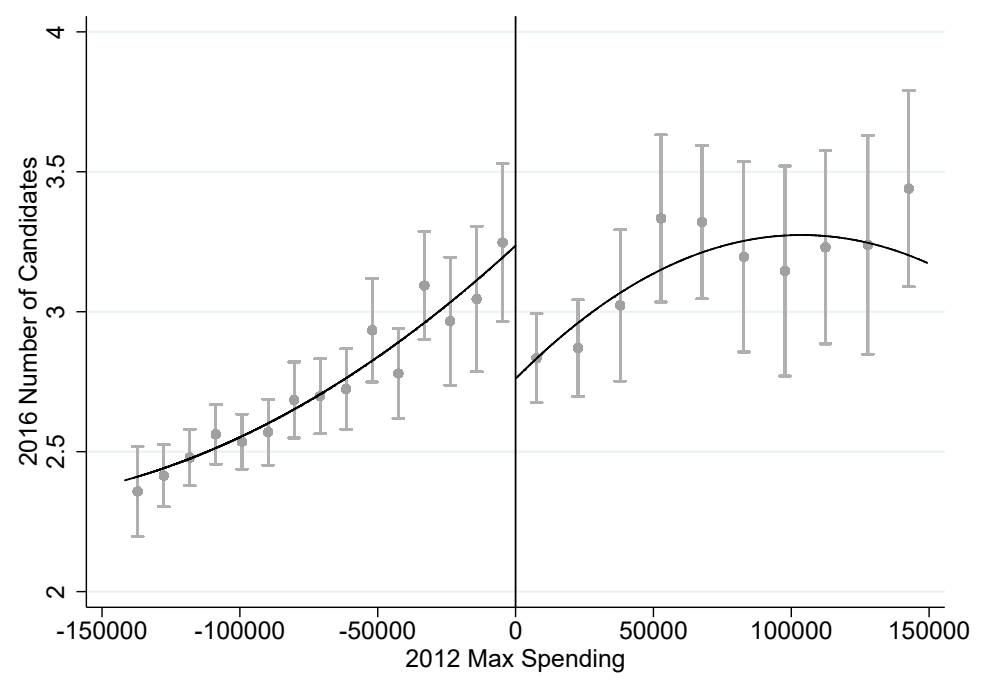

(b) Effective number of candidates

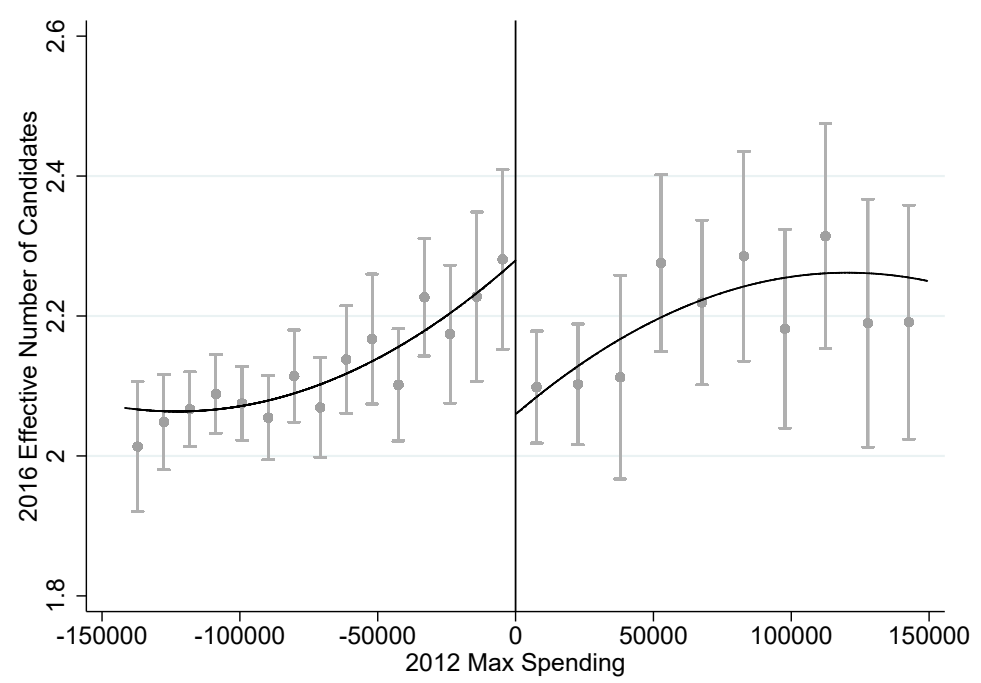

Figure 7: The Effects of Campaign Spending Limits on Political Competition

Notes: This figure plots the results of the regression discontinuity design, where the dependent variable is (a) the number of candidates, and (b) the effective number of candidates. The horizontal axis denotes the difference in maximum spending relative to the discontinuity at $\mathrm{R} \$ 142,857$. In each regression, a global second-order polynomial is estimated on each side of the discontinuity. Each point denotes the sample-average within a bin and its corresponding $95 \%$ confidence interval. 


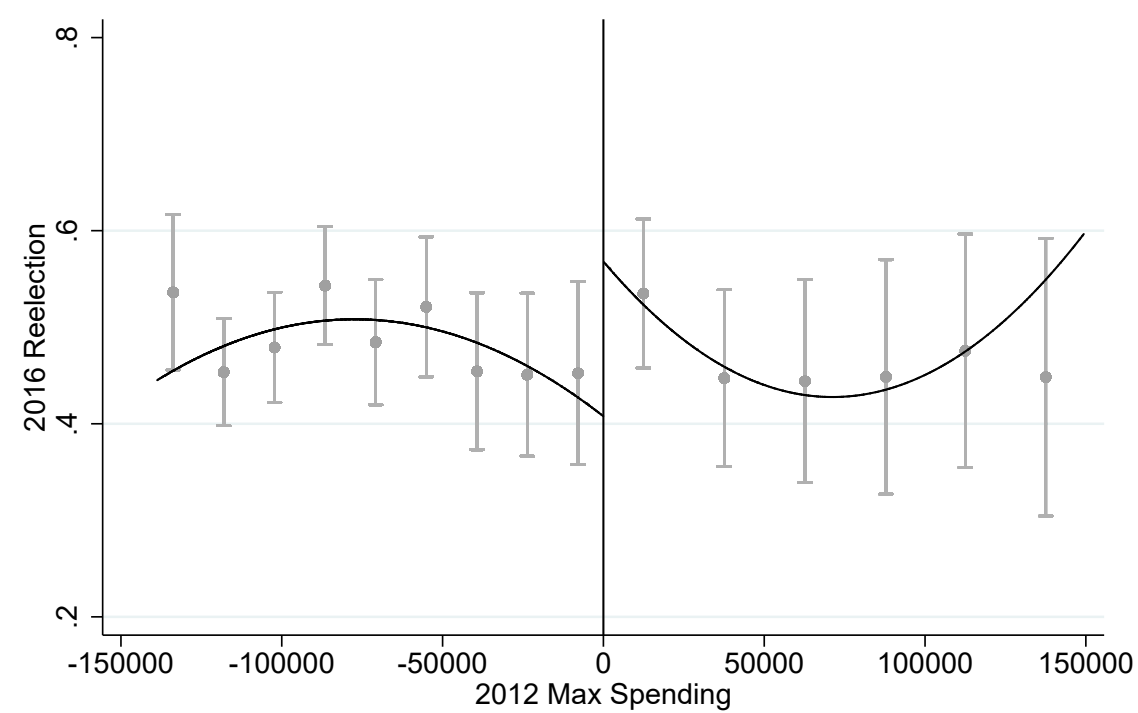

- Sample average within bin $\quad$ Polynomial fit of order 2

\section{Figure 8: The Effect of Campaign Spending Limits on Reelection}

Notes: This figure plots the results of the regression discontinuity design, where the dependent variable is a dummy for whether the incumbent is reelected. The sample is restricted to incumbents who run for reelection. The horizontal axis denotes the difference in maximum spending relative to the discontinuity at $R \$ 142,857$. In each regression, a global second-order polynomial is estimated on each side of the discontinuity. Each point denotes the sample-average within a bin and its corresponding 95\% confidence interval. 
Table 1: Summary Statistics

\begin{tabular}{|c|c|c|c|}
\hline & $\begin{array}{l}\text { Mean } \\
(1)\end{array}$ & $\begin{array}{l}\text { Standard Deviation } \\
\text { (2) }\end{array}$ & $\begin{array}{c}\text { Observations } \\
\text { (3) }\end{array}$ \\
\hline \multicolumn{4}{|c|}{ Panel A: Within-Municipality Average Candidate Characteristics } \\
\hline Campaign spending (R\$1000) & 77.28 & 145.97 & 5562 \\
\hline Campaign contributions $(\mathrm{R} \$ 1000)$ & 74.94 & 122.17 & 5562 \\
\hline Own funds & 29.98 & 54.62 & 5562 \\
\hline Individual donations & 31.15 & 50.38 & 5562 \\
\hline Party donations & 11.35 & 49.79 & 5562 \\
\hline All other donations & 0.15 & 2.09 & 5562 \\
\hline Female & 0.125 & 0.207 & 5562 \\
\hline Age & 49.21 & 11.25 & 5562 \\
\hline High school & 0.830 & 0.249 & 5562 \\
\hline College & 0.505 & 0.333 & 5562 \\
\hline Political experience & 0.944 & 0.620 & 5562 \\
\hline Assets $(\mathrm{R} \$ 1000)$ & 1006.80 & 5483.58 & 5562 \\
\hline Propensity to win & 0.361 & 0.081 & 5562 \\
\hline \multicolumn{4}{|l|}{ Panel B: Municipality Characteristics } \\
\hline Number of candidates & 2.925 & 1.333 & 5562 \\
\hline GDP per capita & 6.080 & 0.501 & 5544 \\
\hline Illiteracy & 0.174 & 0.107 & 5544 \\
\hline Share urban & 0.639 & 0.220 & 5544 \\
\hline Gini coefficient & 0.494 & 0.066 & 5544 \\
\hline Log voters & 9.225 & 1.078 & 5562 \\
\hline Hiring limit & 137.22 & 192.72 & 5562 \\
\hline Open seat & 0.241 & & 5562 \\
\hline \multicolumn{4}{|l|}{ Panel C: Incumbent Outcomes } \\
\hline Reelection & 0.482 & & 2618 \\
\hline Incumbent vote share & 0.468 & 0.184 & 2618 \\
\hline
\end{tabular}

Notes: This table displays means and standard deviations of various characteristics computed for the municipality and incumbent samples. In panel A, statistics on campaign spending, female gender, age, high school and college completion, assets, and propensity to win are computed for municipality-level means. In panel B, the statistics are calculated for municipality-level characteristics. The "open seat" variable is a dummy for whether the seat in 2012 is occupied by a term-limited mayor. In panel $\mathrm{C}$, statistics for reelection and the incumbent vote share are computed for the sample of incumbents who rerun in 2016. 
Table 2: Covariate Smoothness

\begin{tabular}{|c|c|c|c|}
\hline Dependent Variable & $\begin{array}{l}\text { Mean } \\
(1)\end{array}$ & $\begin{array}{c}\text { Observations } \\
\text { (2) }\end{array}$ & $\begin{array}{c}\text { Estimate } \\
\text { (3) }\end{array}$ \\
\hline \multicolumn{4}{|c|}{ Panel A: Municipal Characteristics in 2010} \\
\hline GDP per capita $(\log )$ & $\begin{array}{c}5.911 \\
(0.031)\end{array}$ & 2558 & $\begin{array}{c}0.012 \\
(0.040)\end{array}$ \\
\hline Illiteracy & $\begin{array}{c}0.208 \\
(0.008)\end{array}$ & 2201 & $\begin{array}{l}-0.002 \\
(0.010)\end{array}$ \\
\hline Share Urban & $\begin{array}{c}0.625 \\
(0.014)\end{array}$ & 2419 & $\begin{array}{l}-0.015 \\
(0.018)\end{array}$ \\
\hline Gini Coefficient & $\begin{array}{c}0.511 \\
(0.005)\end{array}$ & 2431 & $\begin{array}{l}-0.000 \\
(0.006)\end{array}$ \\
\hline Population (log) & $\begin{array}{c}9.509 \\
(0.053)\end{array}$ & 1986 & $\begin{array}{c}-0.158 * * \\
(0.068)\end{array}$ \\
\hline \multicolumn{4}{|c|}{ Panel B: Mean Candidate Characteristics in 2012} \\
\hline Number of Candidates & $\begin{array}{c}3.052 \\
(0.086)\end{array}$ & 1763 & $\begin{array}{l}-0.007 \\
(0.108)\end{array}$ \\
\hline Effective Number of Candidates & $\begin{array}{c}2.203 \\
(0.042)\end{array}$ & 1902 & $\begin{array}{l}-0.030 \\
(0.048)\end{array}$ \\
\hline Small Party & $\begin{array}{c}0.425 \\
(0.020)\end{array}$ & 2270 & $\begin{array}{c}0.004 \\
(0.025)\end{array}$ \\
\hline Female & $\begin{array}{c}0.121 \\
(0.013)\end{array}$ & 2553 & $\begin{array}{c}0.022 \\
(0.016)\end{array}$ \\
\hline Age & $\begin{array}{l}47.962 \\
(0.437)\end{array}$ & 2433 & $\begin{array}{c}0.072 \\
(0.548)\end{array}$ \\
\hline High School Degree & $\begin{array}{c}0.853 \\
(0.018)\end{array}$ & 2024 & $\begin{array}{c}0.001 \\
(0.023)\end{array}$ \\
\hline College Degree & $\begin{array}{c}0.509 \\
(0.024)\end{array}$ & 1986 & $\begin{array}{c}0.037 \\
(0.030)\end{array}$ \\
\hline Campaign Spending & $\begin{array}{l}94396.87 \\
(2431.97)\end{array}$ & 1057 & $\begin{array}{l}-1965.04 \\
(2921.36)\end{array}$ \\
\hline Campaign Contributions & $\begin{array}{l}94737.97 \\
(2364.50)\end{array}$ & 1085 & $\begin{array}{l}-2551.47 \\
(2882.86)\end{array}$ \\
\hline Own Funds & $\begin{array}{l}24319.94 \\
(1796.36)\end{array}$ & 1297 & $\begin{array}{c}2572.27 \\
(2464.03)\end{array}$ \\
\hline Individual Donations & $\begin{array}{l}36355.43 \\
(1762.72)\end{array}$ & 1538 & $\begin{array}{l}-1498.32 \\
(2202.32)\end{array}$ \\
\hline Party Donations & $\begin{array}{l}10572.97 \\
(1389.72)\end{array}$ & 1036 & $\begin{array}{l}-2074.31 \\
(1688.48)\end{array}$ \\
\hline Corporate Donations & $\begin{array}{l}15876.27 \\
(1518.43)\end{array}$ & 1233 & $\begin{array}{c}937.79 \\
(2145.03)\end{array}$ \\
\hline
\end{tabular}

Notes: Standard errors are in parentheses. The mean in column (1) is the estimated value of the dependent variable for a municipality at the cutoff point whose spending limit is $\$ \mathrm{R} 108,039$ in 2016. The bandwidth is selected with the optimal procedure by Calonico et al. (2014) and the number of observations is reported in column (2). Each figure in column (3) reports the estimate and standard error for the treatment effect from a separate regression. $* p<0.10, * * p<0.05, * * * p<0.01$. 
Table 3: The Effects of Spending Limits on Campaign Expenditures

\begin{tabular}{lcccccc}
\hline & Mean & Obs & $(1)$ & $(2)$ & $(3)$ & $(4)$ \\
\hline Maximum Spending & 84823.66 & 1068 & $10212.56 * * *$ & $9834.92 * * *$ & $10337.88 * * *$ & $11781.30 * * *$ \\
& $(2283.84)$ & & $(2971.87)$ & $(3280.29)$ & $(2758.98)$ & $(3502.78)$ \\
Mean Spending & 58471.54 & 1274 & $5705.95 * *$ & $4940.07 *$ & $5540.17 * *$ & $6833.53 * *$ \\
& $(1875.60)$ & & $(2461.39)$ & $(2763.56)$ & $(2251.89)$ & $(2946.03)$ \\
Minimum Spending & 32829.54 & 1745 & 988.86 & 16.68 & 1452.29 & -408.74 \\
& $(2090.75)$ & & $(2820.98)$ & $(3175.00)$ & $(2582.36)$ & $(3777.42)$ \\
Total Spending & 169000.64 & 1159 & 7335.85 & 11682.88 & 7156.26 & 12238.92 \\
& $(6006.29)$ & & $(7511.99)$ & $(8425.47)$ & $(6850.61)$ & $(8760.41)$ \\
& & & & & \\
\hline Bandwidth & CCT & CCT & CCT & $75 \%$ CCT & $125 \%$ CCT & CCT \\
Polynomial Order & One & One & One & One & One & Two \\
\hline
\end{tabular}

Notes: Each figure in columns (1)-(4) reports the estimate and standard error of a separate regression. Standard errors are in parentheses. The mean is the estimated value, based on specification (1), of the dependent variable for a municipality at the cutoff point whose spending limit is \$R108,039. The dependent variables are respectively the mean, maximum, minimum, and total campaign expenditures by candidates computed at the municipality-level. The CCT bandwidth is selected with the optimal procedure by Calonico et al. (2014), and the number of observations under this bandwidth is reported in the table. State fixed effects and municipal controls (income per capita, illiteracy, share urban, population, gini coefficient) are included in all regressions. * $p<0.10, * * p<0.05, * * * p<0.01$. 
Table 4: The Effects of Spending Limits on Campaign Contributions

\begin{tabular}{lcccccc}
\hline & Mean & Obs & $(1)$ & $(2)$ & $(3)$ & $(4)$ \\
\hline Overall Contributions & 58270.00 & 1332 & $6179.41^{* *}$ & $5754.40^{* *}$ & $5641.58^{* *}$ & $6988.09 * *$ \\
& $(1845.51)$ & & $(2441.96)$ & $(2732.77)$ & $(2232.75)$ & $(3064.40)$ \\
Own Funds & & & & & & \\
& 23889.92 & 1459 & $4641.85 * *$ & $4487.98^{*}$ & $3648.77 *$ & $4262.16^{*}$ \\
& $(1459.86)$ & & $(2162.27)$ & $(2426.65)$ & $(1963.48)$ & $(2581.21)$ \\
Individual Donations & 25747.75 & 1439 & 200.07 & 280.40 & 489.96 & 266.29 \\
& $(1325.32)$ & & $(1752.67)$ & $(1937.98)$ & $(1621.45)$ & $(2186.17)$ \\
Party Donations & 7074.12 & 1429 & 1210.84 & 1201.15 & 963.01 & 1377.40 \\
& $(790.16)$ & & $(1060.98)$ & $(1200.61)$ & $(968.80)$ & $(1263.92)$ \\
All Other Donations & 113.91 & 1626 & 12.34 & -14.16 & 15.50 & 3.30 \\
& $(45.62)$ & & $(63.50)$ & $(64.28)$ & $(63.73)$ & $(69.08)$ \\
& & & & & & \\
\hline Bandwidth & CCT & CCT & CCT & $75 \%$ CCT & $125 \%$ CCT & CCT \\
Polynomial Order & One & One & One & One & One & Two \\
\hline
\end{tabular}

Notes: Each figure in columns (1)-(4) reports the estimate and standard error of a separate regression. Standard errors are in parentheses. The mean is the estimated value, based on specification (1), of the dependent variable for a municipality at the cutoff point whose spending limit is $\$ R 108,039$. Each dependent variables is a municipality-level mean. "Overall Contributions" is equal to the sum of the four categories: own, individual, party, and other contributions. State fixed effects and municipal controls (income per capita, illiteracy, share urban, population, gini coefficient) are included in all regressions. $* p<0.10, * * p<0.05, * * * p<0.01$. 
Table 5: The Effects of Campaign Spending Limits on Candidate Entry

\begin{tabular}{|c|c|c|c|c|c|c|}
\hline & Mean & Obs & (1) & (2) & (3) & (4) \\
\hline Number of Candidates & $\begin{array}{c}3.187 \\
(0.092)\end{array}$ & 2012 & $\begin{array}{c}-0.256^{* *} \\
(0.102)\end{array}$ & $\begin{array}{c}-0.279 * * \\
(0.119)\end{array}$ & $\begin{array}{c}-0.247 * * * \\
(0.092)\end{array}$ & $\begin{array}{c}-0.279 * * \\
(0.132)\end{array}$ \\
\hline Effective Number of Candidates & $\begin{array}{c}2.253 \\
(0.042)\end{array}$ & 2198 & $\begin{array}{c}-0.143 * * * \\
(0.049)\end{array}$ & $\begin{array}{c}-0.164 * * * \\
(0.056)\end{array}$ & $\begin{array}{c}-0.129 * * * \\
(0.044)\end{array}$ & $\begin{array}{c}-0.184 * * * \\
(0.068)\end{array}$ \\
\hline Propensity to Win & $\begin{array}{c}0.352 \\
(0.005)\end{array}$ & 1985 & $\begin{array}{c}0.020 * * * \\
(0.007)\end{array}$ & $\begin{array}{c}0.022 * * * \\
(0.008)\end{array}$ & $\begin{array}{c}0.018 * * * \\
(0.006)\end{array}$ & $\begin{array}{c}0.022 * * * \\
(0.008)\end{array}$ \\
\hline Small Party & $\begin{array}{c}0.488 \\
(0.021)\end{array}$ & 2166 & $\begin{array}{l}-0.038 \\
(0.026)\end{array}$ & $\begin{array}{l}-0.044 \\
(0.031)\end{array}$ & $\begin{array}{l}-0.037 \\
(0.024)\end{array}$ & $\begin{array}{l}-0.049 \\
(0.030)\end{array}$ \\
\hline Female & $\begin{array}{c}0.156 \\
(0.016)\end{array}$ & 1863 & $\begin{array}{l}-0.030 \\
(0.020)\end{array}$ & $\begin{array}{l}-0.034 \\
(0.023)\end{array}$ & $\begin{array}{l}-0.018 \\
(0.018)\end{array}$ & $\begin{array}{c}-0.043 * \\
(0.025)\end{array}$ \\
\hline Age & $\begin{array}{l}49.094 \\
(0.453)\end{array}$ & 2468 & $\begin{array}{l}-0.364 \\
(0.539)\end{array}$ & $\begin{array}{l}-0.202 \\
(0.608)\end{array}$ & $\begin{array}{l}-0.407 \\
(0.494)\end{array}$ & $\begin{array}{l}-0.154 \\
(0.756)\end{array}$ \\
\hline White & $\begin{array}{c}0.617 \\
(0.022)\end{array}$ & 1771 & $\begin{array}{l}-0.021 \\
(0.027)\end{array}$ & $\begin{array}{l}-0.019 \\
(0.031)\end{array}$ & $\begin{array}{l}-0.013 \\
(0.024)\end{array}$ & $\begin{array}{l}-0.028 \\
(0.033)\end{array}$ \\
\hline College Degree & $\begin{array}{c}0.562 \\
(0.021)\end{array}$ & 2083 & $\begin{array}{l}-0.025 \\
(0.027)\end{array}$ & $\begin{array}{l}-0.017 \\
(0.031)\end{array}$ & $\begin{array}{l}-0.025 \\
(0.025)\end{array}$ & $\begin{array}{c}-0.028 \\
(0.031)\end{array}$ \\
\hline Political Experience & $\begin{array}{c}0.866 \\
(0.040)\end{array}$ & 2254 & $\begin{array}{c}0.062 \\
(0.048)\end{array}$ & $\begin{array}{c}0.053 \\
(0.055)\end{array}$ & $\begin{array}{c}0.044 \\
(0.044)\end{array}$ & $\begin{array}{c}0.056 \\
(0.067)\end{array}$ \\
\hline Wealth $(\log )$ & $\begin{array}{c}11.477 \\
(0.175)\end{array}$ & 1811 & $\begin{array}{l}0.401 * \\
(0.214)\end{array}$ & $\begin{array}{c}0.483 * * \\
(0.247)\end{array}$ & $\begin{array}{c}0.313 \\
(0.194)\end{array}$ & $\begin{array}{c}0.498 * * \\
(0.253)\end{array}$ \\
\hline $\begin{array}{l}\text { Bandwidth } \\
\text { Polynomial Order }\end{array}$ & $\begin{array}{l}\text { CCT } \\
\text { One }\end{array}$ & $\begin{array}{l}\text { CCT } \\
\text { One }\end{array}$ & $\begin{array}{l}\mathrm{CCT} \\
\text { One }\end{array}$ & $\begin{array}{l}75 \% \text { CCT } \\
\text { One }\end{array}$ & $\begin{array}{c}125 \% \mathrm{CCT} \\
\text { One }\end{array}$ & $\begin{array}{l}\text { CCT } \\
\text { Two }\end{array}$ \\
\hline
\end{tabular}

Notes: Each figure in columns (1)-(4) reports the estimate and standard error of a separate regression. Standard errors are in parentheses. The mean is the estimated value, based on specification (1), of the dependent variable for a municipality at the cutoff point whose spending limit is $\$ \mathrm{R} 108,039$. The dependent variables are two measures of the number of candidates who run for office, followed by municipality-level averages of various candidate characteristics. The "Propensity to Win" denotes the propensity for a candidate to win an election based on his observable characteristics (see Table A.1). State fixed effects and municipal controls (income per capita, illiteracy, share urban, population, gini coefficient) are included in all regressions. $* p<0.10, * * p<0.05, * * *<0.01$. 
Table 6: The Effects of Campaign Spending Limits on Incumbents

\begin{tabular}{|c|c|c|c|c|c|c|}
\hline & Mean & Obs & (1) & (2) & (3) & (4) \\
\hline \multicolumn{7}{|l|}{ Panel A: All incumbents } \\
\hline Rerun & $\begin{array}{c}0.605 \\
(0.040)\end{array}$ & 1559 & $\begin{array}{c}0.057 \\
(0.049)\end{array}$ & $\begin{array}{c}0.029 \\
(0.057)\end{array}$ & $\begin{array}{c}0.057 \\
(0.043)\end{array}$ & $\begin{array}{c}0.054 \\
(0.061)\end{array}$ \\
\hline Reelection & $\begin{array}{c}0.226 \\
(0.030)\end{array}$ & 1726 & $\begin{array}{c}0.110 * * * \\
(0.042)\end{array}$ & $\begin{array}{c}0.122 * * \\
(0.048)\end{array}$ & $\begin{array}{c}0.088 * * \\
(0.037)\end{array}$ & $\begin{array}{c}0.110 * * \\
(0.050)\end{array}$ \\
\hline \multicolumn{7}{|c|}{ Panel B: Incumbents who rerun in 2016} \\
\hline Reelection & $\begin{array}{c}0.384 \\
(0.050)\end{array}$ & 762 & $\begin{array}{c}0.160 * * \\
(0.062)\end{array}$ & $\begin{array}{c}0.182 * * \\
(0.072)\end{array}$ & $\begin{array}{c}0.145^{* *} \\
(0.058)\end{array}$ & $\begin{array}{c}0.141 * * \\
(0.068)\end{array}$ \\
\hline Change in Vote Share & $\begin{array}{l}-0.133 \\
(0.024)\end{array}$ & 678 & $\begin{array}{c}0.066 * * \\
(0.030)\end{array}$ & $\begin{array}{c}0.078 * * \\
(0.032)\end{array}$ & $\begin{array}{c}0.055 * * \\
(0.027)\end{array}$ & $\begin{array}{l}0.066^{*} \\
(0.034)\end{array}$ \\
\hline Incumbent Spending & $\begin{array}{l}73442.98 \\
(2903.77)\end{array}$ & 682 & $\begin{array}{c}10311.77 * * \\
(4348.01)\end{array}$ & $\begin{array}{c}9059.49 * * \\
(4514.72)\end{array}$ & $\begin{array}{c}10360.66 * * \\
(4183.28)\end{array}$ & $\begin{array}{c}11370.41 * * \\
(5484.85)\end{array}$ \\
\hline Total Challenger Spending & $\begin{array}{l}98797.86 \\
(5462.11)\end{array}$ & 878 & $\begin{array}{c}1107.77 \\
(7411.32)\end{array}$ & $\begin{array}{c}-715.63 \\
(8117.57)\end{array}$ & $\begin{array}{c}2436.11 \\
(6645.58)\end{array}$ & $\begin{array}{c}1137.01 \\
(9993.36)\end{array}$ \\
\hline Mean Challenger Spending & $\begin{array}{l}49012.44 \\
(2443.98)\end{array}$ & 976 & $\begin{array}{c}3970.59 \\
(3440.95)\end{array}$ & $\begin{array}{c}3699.74 \\
(3784.47)\end{array}$ & $\begin{array}{c}3483.18 \\
(3157.33)\end{array}$ & $\begin{array}{c}4872.82 \\
(4349.70)\end{array}$ \\
\hline Bandwidth & $\mathrm{CCT}$ & CCT & $\mathrm{CCT}$ & $75 \% \mathrm{CCT}$ & $125 \% \mathrm{CCT}$ & CCT \\
\hline Polynomial Order & One & One & One & One & One & Two \\
\hline
\end{tabular}

Notes: Each figure in columns (1)-(4) reports the estimate and standard error of a separate regression. Standard errors in parentheses, clustered by state-party. The mean is the estimated value, based on specification (1), of the dependent variable for a municipality at the cutoff point whose spending limit is $\$ R 108,039$. State and party fixed effects and municipal controls (income per capita, illiteracy, share urban, population, gini coefficient and 2012 incumbent spending) are included in all regressions. In Panel A, the sample consists of all incumbents who are not term-limited. In Panel $\mathrm{B}$, the sample consists of incumbent mayors who choose to rerun in 2016. * $p<0.10$, ** $p<0.05$, *** $p<0.01$. 
Table 7: The Effects of Campaign Spending Limits on Political Selection

\begin{tabular}{|c|c|c|c|c|c|c|}
\hline & Mean & Obs & (1) & (2) & (3) & (4) \\
\hline Propensity to Win & $\begin{array}{c}0.382 \\
(0.008)\end{array}$ & 2112 & $\begin{array}{c}0.017 \\
(0.011)\end{array}$ & $\begin{array}{l}0.022^{*} \\
(0.012)\end{array}$ & $\begin{array}{l}0.016^{*} \\
(0.010)\end{array}$ & $\begin{array}{c}0.020 \\
(0.013)\end{array}$ \\
\hline Female & $\begin{array}{c}0.138 \\
(0.025)\end{array}$ & 2024 & $\begin{array}{c}0.007 \\
(0.032)\end{array}$ & $\begin{array}{l}-0.000 \\
(0.037)\end{array}$ & $\begin{array}{c}0.013 \\
(0.029)\end{array}$ & $\begin{array}{l}-0.004 \\
(0.039)\end{array}$ \\
\hline Age & $\begin{array}{l}49.299 \\
(0.765)\end{array}$ & 2359 & $\begin{array}{l}-0.483 \\
(0.964)\end{array}$ & $\begin{array}{l}-0.649 \\
(1.097)\end{array}$ & $\begin{array}{l}-0.503 \\
(0.883)\end{array}$ & $\begin{array}{c}-0.804 \\
(1.354)\end{array}$ \\
\hline White & $\begin{array}{c}0.634 \\
(0.032)\end{array}$ & 2204 & $\begin{array}{c}0.002 \\
(0.040)\end{array}$ & $\begin{array}{c}0.003 \\
(0.046)\end{array}$ & $\begin{array}{c}0.003 \\
(0.036)\end{array}$ & $\begin{array}{c}0.001 \\
(0.047)\end{array}$ \\
\hline College Degree & $\begin{array}{c}0.547 \\
(0.031)\end{array}$ & 2520 & $\begin{array}{c}0.002 \\
(0.039)\end{array}$ & $\begin{array}{c}0.004 \\
(0.044)\end{array}$ & $\begin{array}{c}0.000 \\
(0.036)\end{array}$ & $\begin{array}{c}0.025 \\
(0.056)\end{array}$ \\
\hline Political Experience & $\begin{array}{c}0.898 \\
(0.075)\end{array}$ & 1903 & $\begin{array}{c}0.059 \\
(0.094)\end{array}$ & $\begin{array}{c}0.088 \\
(0.109)\end{array}$ & $\begin{array}{c}0.041 \\
(0.085)\end{array}$ & $\begin{array}{c}0.070 \\
(0.104)\end{array}$ \\
\hline Wealth (log) & $\begin{array}{l}11.749 \\
(0.230)\end{array}$ & 2814 & $\begin{array}{l}0.514 * \\
(0.266)\end{array}$ & $\begin{array}{l}0.525^{*} \\
(0.301)\end{array}$ & $\begin{array}{l}0.436 * \\
(0.242)\end{array}$ & $\begin{array}{c}0.573 \\
(0.359)\end{array}$ \\
\hline Worker's Party (PT) & $\begin{array}{c}0.033 \\
(0.012)\end{array}$ & 2608 & $\begin{array}{l}-0.003 \\
(0.015)\end{array}$ & $\begin{array}{l}-0.005 \\
(0.017)\end{array}$ & $\begin{array}{l}-0.000 \\
(0.013)\end{array}$ & $\begin{array}{l}-0.005 \\
(0.019)\end{array}$ \\
\hline Bandwidth & $\mathrm{CCT}$ & $\mathrm{CCT}$ & $\mathrm{CCT}$ & $75 \% \mathrm{CCT}$ & $125 \% \mathrm{CCT}$ & $\mathrm{CCT}$ \\
\hline Polynomial Order & One & One & One & One & One & Two \\
\hline
\end{tabular}

Notes: Each figure in columns (1)-(4) reports the estimate and standard error of a separate regression. Standard errors are in parentheses. The mean is the estimated value, based on specification (1), of the dependent variable for a municipality at the cutoff point whose spending limit is $\$ R 108,039$. The dependent variables are characteristics of the winning candidates. The "Propensity to Win" dependent variable denotes the propensity for a candidate to win an election based on his observable characteristics (see Table A.1). State fixed effects and municipal controls (income per capita, illiteracy, share urban, population, gini coefficient) are included in all regressions. $* p<0.10, * * p<0.05$, *** $p<0.01$. 
Table 8: The Effects of Campaign Spending Limits on the Campaign Contributions of Winners

\begin{tabular}{lcccccc}
\hline & Mean & Obs & $(1)$ & $(2)$ & $(3)$ & $(4)$ \\
\hline Overall Contributions & 76140.38 & 1093 & $9136.78^{* * *}$ & $9187.39 * *$ & $8617.55^{* * *}$ & $10628.05^{* *}$ \\
& $(2542.77)$ & & $(3479.48)$ & $(3888.34)$ & $(3193.54)$ & $(4170.59)$ \\
Own Funds & & & & & & \\
& 29448.08 & 1361 & $10747.16^{* * *}$ & $11125.72 * * *$ & $9352.32 * * *$ & $11907.39 * * *$ \\
& $(2541.11)$ & & $(3711.19)$ & $(4162.91)$ & $(3358.36)$ & $(4594.10)$ \\
Individual Donations & 38930.25 & 1163 & -3208.61 & -3639.71 & -2809.18 & -3728.12 \\
& $(2550.80)$ & & $(3479.94)$ & $(3847.64)$ & $(3222.52)$ & $(4139.73)$ \\
Party Donations & 7964.54 & 1227 & 1195.99 & 2455.58 & 528.46 & 3290.46 \\
& $(1442.29)$ & & $(2010.14)$ & $(2171.93)$ & $(1879.62)$ & $(2472.87)$ \\
All Other Donations & 245.42 & 1846 & -24.93 & -78.32 & 11.33 & -76.18 \\
& $(117.59)$ & & $(172.86)$ & $(181.01)$ & $(167.22)$ & $(196.99)$ \\
& & & & & & \\
\hline Bandwidth & CCT & CCT & CCT & $75 \%$ CCT & $125 \%$ CCT & CCT \\
Polynomial Order & One & One & One & One & One & Two \\
\hline
\end{tabular}

Notes: Each figure in columns (1)-(4) reports the estimate and standard error of a separate regression. Standard errors are in parentheses. The mean is the estimated value, based on specification (1), of the dependent variable for a municipality at the cutoff point whose spending limit is \$R108,039. The "Overall Contributions" dependent variable is equal to the sum of the four categories: own, individual, party, and other contributions. State fixed effects and municipal controls (income per capita, illiteracy, share urban, population, gini coefficient) are included in all regressions. ${ }^{*} p<0.10, * * p<0.05, * * * p<0.01$.

Table 9: The Effects of Campaign Spending Limits on Voter Information

\begin{tabular}{lcccccc}
\hline & Mean & Obs & $(1)$ & $(2)$ & $(3)$ & $(4)$ \\
\hline Turnout & 0.839 & 2645 & -0.005 & -0.005 & -0.005 & -0.005 \\
& $(0.003)$ & & $(0.003)$ & $(0.004)$ & $(0.003)$ & $(0.004)$ \\
Share of Blank or Invalid Votes & 0.069 & 2193 & 0.012 & 0.013 & 0.010 & 0.014 \\
& $(0.005)$ & & $(0.007)$ & $(0.008)$ & $(0.007)$ & $(0.009)$ \\
& & & & & & \\
\hline Bandwidth & CCT & CCT & CCT & $75 \%$ CCT & $125 \%$ CCT & CCT \\
Polynomial Order & One & One & One & One & One & Two \\
\hline
\end{tabular}

Notes: Each figure in columns (1)-(4) reports the estimate and standard error of a separate regression. Standard errors are in parentheses. The mean is the estimated value, based on specification (1), of the dependent variable for a municipality at the cutoff point whose spending limit is $\$ R 108,039$. The "Turnout" dependent variable is the number of votes divided by the number of eligible voters. The "Share of Blank or Invalid Votes" dependent variable denotes the number of votes cast which are either blank or invalid divided by the number of eligible voters. State fixed effects and municipal controls (income per capita, illiteracy, share urban, population, gini coefficient) are included in all regressions. $* p<0.10, * * p<0.05, * * * p<0.01$. 


\section{A Appendix}

\section{Proof of Proposition 2}

\section{Proposition 2}

(a) If all candidates are symmetric with respect to quality, i.e. if $a_{i}=a \forall i$ for some $a>0$, then equilibrium total expenditures increase in the spending limit: $\partial_{+} \sum_{i} x_{i}^{*}(\bar{x}) \geq 0$ and $\partial_{-} \sum_{i} x_{i}^{*}(\bar{x}) \geq$ 0 . However, equilibrium total expenditures need not increase if candidates are asymmetric with respect to quality.

(b) The number of entrants in equilibrium decreases in the spending limit: $\partial_{+} m(\bar{x}) \leq 0$.

(c) The average ability of entrants is increasing in the spending limit if the marginal cost is constant across candidates. Moreover, the average marginal cost of expenditures of entrants is decreasing in the spending limit if ability is constant across candidates: $\partial_{+} \frac{\sum_{j \in M} a_{j}}{m} \geq 0$ if $c_{i}=c$ for all $i$, and $\partial_{+} \frac{\sum_{j \in M} c_{j}}{m} \leq 0$ if $a_{i}=a$ for all $i$.

(d) An entrant's equilibrium probability of election

(i) is unchanged by an increase in the spending limit if all entrants spend at the cap or if all entrants spend less than the cap: $\partial_{-} p_{i}(\bar{x})=0$ if $i \in B \forall i \in M$ or if $i \in N B \forall i \in M$;

(ii) decreases in the spending limit if the candidate spends less than the cap and at least one other candidate spends at the cap: $\partial_{-} p_{i}(\bar{x})<0$ if $i \in N B$ and $B$ is nonempty;

(iii) increases in the spending limit if the candidate spends at the cap and at least one other candidate spends less than the cap: $\partial_{-} p_{i}(\bar{x})>0$ if $i \in B$ and $N B$ is nonempty.

Proof: (a) Let $G(Y, \bar{x})=S(Y, \bar{x})-1$. We know that $G$ is greater than zero for sufficiently small values of $Y$, less than zero for sufficiently large values of $Y$, strictly decreasing in $Y$ whenever $G>-1$, and continuous. By equation (6), it follows that the following partial derivatives with respect to $\bar{x}$ are increasing: $\partial_{+} G(Y, \bar{x}) \geq 0$ and $\partial_{-} G(Y, \bar{x}) \geq 0$ for all $Y$. Since $Y^{*}(\bar{x})$ is defined by $G\left(Y^{*}, \bar{x}\right)=0$, it follows that $\partial_{+} Y^{*}(\bar{x}) \geq 0$ and $\partial_{-} Y^{*}(\bar{x}) \geq 0$. If candidates are symmetric with respect to quality, then $\sum_{i} x_{i}^{*}(\bar{x})=Y^{*} / a$ and the result follows. If candidates are asymmetric with respect to quality, then total expenditures may increase or decrease when increasing the spending cap.

(b) From part (a), we have that $\partial_{+} Y^{*}(\bar{x}) \geq 0$, that is, total inputs are weakly increasing in the spending cap. The result then follows from equation (9). Note that $\partial_{-} m(\bar{x})=0$ because the interval 
$M$ is open.

(c) Same as (b).

(d) We consider the left-hand derivatives so that membership in each set is constant when $\bar{x}$ is increased infinitesimally.

(i) Suppose that $i \in B \forall i \in M$. Then $\partial_{-} p_{i}^{*}(\bar{x})=\frac{\sum_{j \in M} a_{j} \bar{x} a_{i}-a_{i} \bar{x} \sum_{j \in M} a_{j}}{\left(\sum a_{j} \bar{x}\right)^{2}}=0$. Suppose that $i \in N B$ $\forall i \in M$. Then $\partial_{-} x_{i}^{*}(\bar{x})=0$ for all $i$ and hence $\partial_{-} p_{i}^{*}(\bar{x})=0$.

(ii) We proceed by contradiction. Let $i \in N B$ and suppose that $\partial_{-} p_{i}^{*}(\bar{x}) \geq 0$. Then, taking the leftderivative of $p_{i}^{*}(\bar{x})$, it follows that $a_{i}\left(\sum_{j \in N} a_{j} x_{j}^{*}\right) \partial_{-} x_{i}(\bar{x})-a_{i} x_{i}^{*}\left(\sum_{j \in N} a_{j} \partial_{-} x_{j}^{*}(\bar{x})\right) \geq 0$. This expression can be rewritten as $Y^{*}\left(1-\frac{2 c_{i} Y^{*}}{a_{i}}\right) \partial_{-} Y^{*}(\bar{x}) \geq Y^{*}\left(1-\frac{c_{i} Y^{*}}{a_{i}}\right) \partial_{-} Y^{*}(\bar{x})$ by substituting equation (7) and the definition of $Y$. Since $Y^{*}>0$ and $\partial_{-} Y^{*}(\bar{x})>0$ because the set $B$ is non-empty, this expression simplifies to $\frac{c_{i} Y^{*}}{a_{i}} \leq 0$, a contradiction.

(iii) By part (ii), it must be the case that $\partial_{-} \sum_{j \in B} p_{j}^{*}(\bar{x})>0$. Differentiating equation (2), it follows that $\sum_{j \in B} a_{j}\left[Y^{*}-\bar{x} \partial_{-} Y^{*}(\bar{x})\right]>0$. Thus, it follows that $\sum_{j \in B} a_{j} \partial_{-} p_{i}(\bar{x})>0$ for all $i \in B$ and the result follows immediately. 
Table A.1: Probability of Winning the Election

\begin{tabular}{|c|c|}
\hline & $\begin{array}{c}(1) \\
\text { Winner of the Election }\end{array}$ \\
\hline Age & $\begin{array}{c}-0.0167^{* * *} \\
(0.00298)\end{array}$ \\
\hline Age Squared & $\begin{array}{l}0.0000161^{* * *} \\
(0.00000339)\end{array}$ \\
\hline Female & $\begin{array}{l}-0.235^{* * *} \\
(0.0878)\end{array}$ \\
\hline White & $\begin{array}{l}-0.254 \\
(0.388)\end{array}$ \\
\hline Black & $\begin{array}{l}-0.623 \\
(0.437)\end{array}$ \\
\hline Brown & $\begin{array}{l}-0.398 \\
(0.392)\end{array}$ \\
\hline High School & $\begin{array}{c}-0.119 \\
(0.0828)\end{array}$ \\
\hline College & $\begin{array}{l}-0.0494 \\
(0.0625)\end{array}$ \\
\hline Log Assets & $\begin{array}{l}0.0435^{* * *} \\
(0.00902)\end{array}$ \\
\hline Incumbent & $\begin{array}{l}0.612^{* * *} \\
(0.0732)\end{array}$ \\
\hline Political Experience & $\begin{array}{l}0.0560^{* *} \\
(0.0262)\end{array}$ \\
\hline $\begin{array}{l}\text { Party Fixed Effects } \\
\text { Observations }\end{array}$ & $\begin{array}{c}\text { Yes } \\
6438\end{array}$ \\
\hline
\end{tabular}

Notes: Robust standard errors are in parentheses. The sample is restricted to observations that are excluded from the RD regressions. The dependent variable is equal to one if the candidate wins the election and zero otherwise. The regression also controls for party fixed effects. $* p<0.10, * * p<0.05$, *** $p<0.01$. 